\title{
Prosocial Compensation Following a Service Failure: Fulfilling an Organization's Ethical and Philanthropic Responsibilities
}

\author{
Jean-Pierre Thomassen ${ }^{1} \cdot$ Marijke C. Leliveld $^{2} \cdot$ Kees Ahaus $^{1} \cdot$ Steven Van de Walle ${ }^{3}$
}

Received: 3 July 2017 / Accepted: 4 August 2018 / Published online: 25 August 2018

(c) The Author(s) 2018

\begin{abstract}
Prosocial compensation (PC) is a corporate social responsibility (CSR) practice that involves donating money to a charitable cause on behalf of customers as a means to compensate them for their loss after a service failure. In order to determine the effectiveness of PC, we carried out three experiments while also comparing its effectiveness within private and public settings. Experiment 1 focused on the signaling effects of communicating the promise to offer PC to potential customers in the event of service failure. Results show that, in both private and public settings, $\mathrm{PC}$ has positive effects on corporate image, credibility, and word-of-mouth intent. More significantly, PC improved one's CSR image, whereas more tangible compensation, such as a gift voucher, did not. Experiments $2 \mathrm{~A}$ and $2 \mathrm{~B}$ focused on the effects of offering $P C$ after a service failure on perceptions of justice. Results show that PC contributes to perceived distributive justice, procedural justice, and post-recovery satisfaction in both private and public settings. Our study showed that PC could be a relevant new CSR practice for organizations wanting to enhance theirs CSR image while contributing to fulfilling their ethical and philanthropic CSR responsibilities. We discuss the implications of our findings and offer several avenues for follow-up research on this initial study on PC.
\end{abstract}

Keywords Corporate philanthropy $\cdot$ Justice theory $\cdot$ Prosocial compensation $\cdot$ Service guarantee $\cdot$ Signaling theory

\section{Introduction}

CSR is increasingly becoming a mainstream corporate development (Bolton and Mattila 2015) and seen as a determinant of an organization's success (Kiessling et al. 2016). It is important to distinguish the ethical and philanthropic dimensions of companies' CSR responsibilities from the economic and legal dimensions (Carroll 1991; Wood 2010).

Marijke C. Leliveld

M.C.Leliveld@rug.nl

Jean-Pierre Thomassen

J.P.R.Thomassen@rug.nl

Kees Ahaus

C.T.B.Ahaus@rug.nl

Steven Van de Walle

Steven.vandewalle@kuleuven.be

1 Department of Operations, University Groningen, Groningen, The Netherlands

2 Department of Marketing, University of Groningen, P.O. Box 800, 9700 AV Groningen, The Netherlands

3 Public Governance Institute, KU Leuven, Leuven, Belgium
As an example of a response to their ethical responsibilities, organizations may use fair and just recovery procedures in the event of service failures. In terms of their philanthropic responsibilities, they use practices such as making donations to charitable causes and employee volunteering. In this study, we introduce prosocial compensation (PC). This is a proactive corporate philanthropic practice where the company donates money following a service failure to a charitable cause on behalf of its customers as a means to compensate them for their losses. In effect, $\mathrm{PC}$ is the symbiosis of corporate donations and service guarantees. A service guarantee is an explicit and formal promise made by an organization to achieve certain service quality levels. It is through the compensation offered as a part of the service guarantee that the connection is made with corporate donations. As an example, a leasing company offers business customers a service guarantee that includes six service promises. For each promise violated, the organization donates 200 euro to a cause of the customer's choosing (Ahaus and De Haan 2010). We will argue that PC, as psychological compensation for the customer, could be an attractive alternative for the often-used more-tangible types of compensation such 
as money back, discounts, gift vouchers, or free goods and services (e.g., Lii and Lee 2012).

As such, PC could contribute to the corporate ethical responsibility of being just and fair to customers by being transparent and by offering customers compensation for their loss as a result of a service failure. PC contributes to philanthropic responsibilities by supporting charitable causes. As with other CSR practices (Robinson et al. 2012; Plewa et al. 2015), PC could improve customers' evaluations of aspects such as CSR image, corporate image, perceived justice, and post-recovery satisfaction, plus the behavioral word-ofmouth (WOM) intent. In Experiment 1 (US citizens sample, $N=603$ ), we investigate whether explicitly communicating the promise to offer PC after a service failure is effective in influencing customers' evaluations of the organization even when no service failure occurs. We show that PC leads to a significantly larger improvement in CSR image than more tangible compensation such as a gift voucher. Offering PC also leads to improved corporate image, credibility, and WOM-intent although only to a similar extent as tangible compensation. PC thus seems to be an effective practice for communicating an organization's engagement with CSR to its customers. These findings contribute to signaling theory (Connelly et al. 2011; Spence 1974) by showing that not only tangible types but also psychological types of compensation, such as PC, have positive signaling effects (e.g., Ostrom and Iacobucci 1998).

In Experiments 2A (student sample, $N=148$ ) and 2B (mainly US citizens sample, $N=596$ ), we focused on the effectiveness of offering $P C$ after a service failure in fulfilling the organization's ethical responsibility to be just and fair by restoring perceived justice. The idea of PC is that it can be used as a service recovery tool to make up for a service failure and return the customer to a state of satisfaction (Mattila 2001). Therefore, we studied the effects of offering PC (compared to offering no compensation and tangible compensation) on customers' evaluations of perceived justice and post-recovery satisfaction. We found that PC leads to more positive levels of distributive justice, procedural justice, and post-recovery satisfaction than offering no compensation, and thus contributes to fulfilling the organization's ethical responsibility, although offering tangible compensation does better. These findings contribute to justice theory (Adams 1965) in service recovery research (Vázques-Casielles et al. 2010) by showing that psychological compensation, such as PC, has positive effects on perceived justice and satisfaction.

In our three experiments, we manipulated the choice of charity and the type of sector. First, we manipulated choice by using two types of PC: one where the organization predetermined a single charitable cause and one where the customer could freely choose their own cause. Despite existing research showing the positive effects of choice on customers' evaluations (Mattila and Cranage 2005; Robinson et al. 2012), our experiments failed to find this effect. Second, in order to broaden the generic context of the effects of PC, we studied its effect within both private and public settings. Despite the potential public-private differences-differences in corporate image, the limited use of compensation and service guarantees in public settings (Van de Walle 2016) and public organizations being financed by the taxpayers-we found almost no differences in the effects of PC in public and private settings (cf. Thomassen et al. 2017).

Below, we first present the relevant theory on CSR, corporate philanthropy, and PC. To build our hypotheses, that are later tested in Experiment 1, we use theory on signaling effects. This is followed by the methodology and the results of this first experiment. Then, we use insights from justice theory to form hypotheses regarding the justice effects of PC, similarly followed by a description of the method and results of Experiments $2 \mathrm{~A}$ and $2 \mathrm{~B}$. Finally, this paper ends with a general discussion, including six avenues for further research and some managerial implications of our findings.

\section{Theory}

\section{Corporate Social Responsibility}

Corporate social responsibility (CSR) is a corporate commitment to maximize a company's long-term beneficial impact on societal wellbeing while minimizing any harmful effects on society by being responsible for its customers, shareholders, employees and society in general, even if this requires sacrifices from the organization (Bolton and Mattila 2015; Carroll and Shabana 2010). Carroll (1991) proposes conceptualizing CSR as consisting of four dimensions that he refers to as 'the pyramid of corporate social responsibility' (Carroll and Shabana 2010; Gautier and Pache 2015; Wood 2010). The economic responsibility of a company to produce goods/services and make profits as the basis for corporate continuity is viewed as the most fundamental dimension and is the basis for the other dimensions. Next, there are the legal responsibilities (to pursue the corporate mission within the framework of the law) and then the ethical responsibilities. These are activities and practices expected by customers even though they are not codified into law (Carroll 1991). Customers should, for example, be treated right, just, and fair (Larsen and Lawson 2013). The fourth dimension consists of corporate philanthropic responsibilities. These are seen as the purely voluntary actions of a 'good corporate citizen' that go beyond ethical obligations.

Companies are under increasing pressure from shareholders, customers, employees, and society to enhance their social activities (Cantrell et al. 2015; Kiessling et al. 2016; Pérez and del Bosque 2015). CSR initiatives are a corporate 
response to this environment in which regulations, non-governmental actors, and institutionalized norms set expectations about appropriate organizational behavior (Campbell 2007). As such, CSR has transformed from being a 'goodwill' concept into a mainstream development (Bolton and Mattila 2015; Kiessling et al. 2016) and a key determinant of long-term performance and corporate success (Kiessling et al. 2016). First, by engaging in CSR, companies face fewer risks, and avoid customer and activist boycotts (Groza et al. 2011; Pérez and del Bosque 2013a). Second, CSR can have a positive impact on public opinion (Pfau et al. 2008) and on customers' affective and behavioral responses (Bolton and Mattila 2015). Being socially responsible as an organization can enhance relationships with customers (Kang and Hustvedt 2014), improve customer satisfaction, and increase the company's market value (Luo and Bhattacharya 2006).

Note that in the current research, we take a strong focus on how CSR activity is perceived by customers (cf. Carroll 1991). More recent developments suggest that CSR should not only consider customers to be the "key drivers of companies' social initiatives" (Wang et al. 2016, p. 535), but also study the engagement of employees in CSR activities, and the various levels-individual, organizational, institutionalin which CSR can play a role (Aguinis and Glavas 2012). We fully acknowledge these new developments, but as the main topic of study is prosocial compensation-a CSR activity focusing on customers - we first need to understand the individual customer's perspective, before we can integrate that into multilevel research and other stakeholders. Moreover, recent insights on CSR in management research (Wang et al. 2016) suggest that disentangling different elements of CSR improves the understanding of CSR activities. In line with this view, rather than studying CSR on an aggregate level, we focus on two specific elements of CSR, that is taking care of customers and doing good to society. Both are discussed below in more detail.

\section{Corporate Ethical Responsibilities}

Carroll's third dimension, 'ethical responsibilities' consists of "standards, norms or expectations about fairness and justice and embrace those activities and practices that are expected by customers even though they are not codified into law" (Carroll 1991, p. 41). In the context of our research, and based on Carroll (1991) and Carroll and Shabana (2010), ethical corporate responsibilities can be defined as those standards, norms, and expectations that reflect a concern for what customers regard as fair, just, honest, or in keeping with or protecting their moral rights. Pérez and del Bosque (2013a) give examples of corporate ethical activities such as investing in ethical behavior (ethics officers, ethics committees, codes of ethics, training programs, and incentive programs), corporate disclosures (reports, press releases, and websites) and trust marks (certifications and memberships).

Although these ethical responsibilities are not coded into law, companies have moral obligations translated into consumer rights and principles (Larsen and Lawson 2013). Examples are the Rights to Safety, to be Informed, to Choose, to be Heard, to be Satisfied with the fulfillment of Basic Needs, to be Redressed, to receive Consumer Education, and to contribute to a Healthy and Sustainable Environment (Consumers International 2009). The Right to Redress is "to receive a fair settlement of just claims, including compensation for misrepresentation, shoddy goods or unsatisfactory services" (Consumers International 2009, p. 516). Underpinning this is the Right of Fairness in Exchange in terms of value and equity derived from a transaction (Larsen and Lawson 2013). At the base of this is the Right to receive Appropriate Service, which relates to an holistic expectation that pervades the whole shopping experience (Larsen and Lawson 2013) from a service-dominant logic approach where customers are placed at the heart of service design and operations (Lusch and Vargo 2014). Finally, there is the 'Right to Quality' (Larsen 1998) that is also endorsed in the 1999 revisions of the United Nations' Consumer Policy Framework (United Nations 2003). This right is concerned with "the product or service fulfilling its purpose in an acceptable way and providing sufficient value in both exchange and use" (Larsen and Lawson 2013, p. 521). To acknowledge these consumer rights and to inform customers about their rights, companies may use contracts, codes of conduct, warranties, codes of ethics, and service guarantees. By doing so, they create transparency such that customers know what they can expect, which can be seen as ethical behavior (the third dimension of Carroll's pyramid).

\section{Corporate Philanthropic Responsibilities}

Carroll's (1991) fourth dimension, 'philanthropic responsibilities,' consists of voluntary actions that support being a good corporate citizen within the environmental and social fields. Examples of environmental actions are active participation in environmental conservation, recycling programs, use of green materials, developing non-animal testing procedures, and fighting deforestation and global warming. Within the social field, actions can be related to supporting charitable causes, sponsoring cultural activities, taking diversity initiatives, supporting community events, providing on-site childcare for employees, and supporting local businesses.

Some scholars (e.g., Gautier and Pache 2015) use a narrower definition of corporate philanthropy. In this narrower context, it is defined as "the voluntary business giving of money, time or in-kind goods, without any direct commercial benefit, to one or more organizations whose core purpose is to benefit the community's welfare" (Madden et al. 
2006, p. 49). It is a form of cross-sector partnership between a company and a non-profit organization (Liket and Simaens 2015). Unlike individual philanthropy (e.g., Andreoni 2006), where many acts of generosity are informal and spontaneous, corporate philanthropy is an organized phenomenon. It takes place within complex and rationalized organizations, with formalized action plans (Gautier and Pache 2015).

As with CSR in general, there is a sense of there being a social expectation that companies will practice philanthropy. Gautier and Pache (2015) offered three different motives for engaging in corporate philanthropy. One motive for companies is a commitment to the common good (altruism) without any reciprocity expected for their giving. A second motive is a community investment: companies see it as a long-term investment from which they will ultimately benefit. Finally, corporate philanthropy is also used as a marketing practice to increase sales with a direct commercial profit (Varadarajan and Menon 1988). One observes that the third motive falls outside the narrow definition of Madden et al. (2006, see paragraph above). Nevertheless, corporate philanthropy has evolved from an altruistic practice to a strategic management practice and an investment that provides companies with a competitive advantage (Cantrell et al. 2015). As a non-price differentiating factor (Gautier and Pache 2015), corporate philanthropy induces actual and potential customers to have a more favorable corporate image (Brown and Dacin 1997), offers a better and differential competitive advantage (Cantrell et al. 2015), improves relations with customers who are more satisfied (Luo and Bhattacharya 2006) and loyal to the products and services (Luo 2005), ultimately leading to increased sales and a better financial performance (Lev et al. 2010).

Although PC has not yet been studied, a corporate philanthropy marketing activity that shares many similarities with PC that has been extensively studied is cause-related marketing. This is the practice of donating an amount to a charitable cause every time a customer buys a specific product or service (Howie et al. 2015; Varadarajan and Menon 1988). In essence it is "the process of formulating and implementing marketing activities that are characterized by an offer from the company to contribute a specified amount to a designated cause when customers engage in revenue-providing exchanges that satisfy organizational and individual objectives" (Varadarajan and Menon 1988, p. 60). Cause-related marketing allows companies to simultaneously pursue both financial and prosocial objectives. Companies create mutual value and equity for customers through the act of giving (Kiessling et al. 2016). Cause-related marketing campaigns lead to a more positive corporate image (Kang and Hustvedt 2014; Varadarajan and Menon 1988), a more positive CSR image (Chernev and Blair 2015), more positive switching behavior (Smith and Alcorn 1991), and increased purchase intentions (Brown and Dacin 1997; Howie et al. 2015;
Strahilevitz and Meyers 1998). Given their similarities, we would expect PC to also have such positive effects.

\section{Prosocial Compensation}

In general, tangible types of compensation such as money back, gift vouchers, and free products/services are used as a recovery instrument to offset customers' experienced losses as a consequence of a service failure (e.g., Lii and Lee 2012). However, intangible and more psychological types of compensation are also used. For example, the parking department of a large municipality offered its customers a service guarantee with five specific service promises including waiting no longer than $15 \mathrm{~min}$ at the reception desk and a reaction to any letters within 2 weeks. If the department failed to meet one of these promises, the customer could select either a tangible gift or have 12.50 euro donated to a charitable cause (The Hague 2005). As such, this municipality used both tangible compensation (the gift) and PC. This PC could be seen as contributing to the third and fourth dimensions of Carroll's (1991) 'pyramid of corporate social responsibility.' It contributes to corporate philanthropic responsibilities (the fourth dimension) by offering donations to good causes, and contributes to corporate ethical responsibilities (the third dimension) by offering customers compensation after a service failure and increasing fairness and justice even though offering compensation is not codified into law. Further, PC contributes to four ethical consumer rights (Larsen and Lawson 2013). First, because PC is explicitly communicated in the form of a promise, it contributes to customers' Right to be Informed. Customers know what they can expect and what the consequences for the organization are when the promise is violated. Second, by offering compensation in the form of PC after a service failure, it contributes to the customers' Right to be Redressed. Third and fourth, the promised quality levels in the service guarantee address the Right to Quality and the Right to Appropriate Service. In this way, $\mathrm{PC}$ is able to contribute to delivering a superior customer value.

With a similar consequence to cause-related marketing, in which a donation follows the purchase of a certain product or service, with PC the donation to a cause follows a service failure. The win-win aspect of PC is that it aims to satisfy customers' demands while, at the same time, allowing the company to meet its philanthropic responsibilities. The company contributes to being a good corporate citizen and to its philanthropic responsibilities by contributing resources to charitable causes.

An interesting aspect of $\mathrm{PC}$ is that it combines the practices of corporate philanthropy and service guarantees, a concept intensively studied in the marketing and services management literature (for an overview: see Hogreve and Gremler 2009). A service guarantee is defined as "an explicit 
promise made by a service provider to: (a) deliver a certain level of service to satisfy the customer, and (b) compensate the customer if the service is not sufficiently delivered" (Hogreve and Gremler 2009, p. 324). These service guarantees generally consist of one or more promises (the scope), the compensation in the event of a service failure, and the payout process. In the context of a service guarantee, a 'service failure' is a violation of the service guarantee where the service level offered fails to meet one or more promises in the service guarantee. Here, a customer could experience economic (e.g., money, time) and/or social (e.g., status, esteem) losses (Kim and Ulgado 2012) that, regardless of who was responsible (Magnini et al. 2007), could lead to negative feelings and responses (Siu et al. 2013). It is through this compensation that the link between corporate philanthropy and service guarantees is made.

\section{Researching Signaling and Justice Effects of Prosocial Compensation}

This study has two empirical components. First, we are interested in the effects of explicitly communicating the promise to offer PC. In our first experiment, we conducted research among potential customers visiting the website of an organization. We investigated the effects on CSR image of two types of PC (one with a fixed cause predetermined by the organization and another where the customer could chose the cause), of not offering compensation and offering tangible compensation. We also investigated the effects on corporate image, perceived credibility, and WOM-intent. Besides investigating the effect of choice, we also simulated public and private settings to see if this played a role. In daily life, citizens, as customers, are dependent on very different public services such as garbage collection and the issuing of formal documents such as driving licenses, passports, and visas. Many of these services are offered in a monopolistic situation where customers do not have the possibility to choose. As such, the aim of using PC in public settings would not be to gain market share and improve the competitive position, but to improve one's image and relationship with customers. Despite the importance of public services in the service arena, CSR research seems to largely ignore this sector. In fact, the effects of public CSR practices on customers' evaluations have received little attention in the public management literature. Second, we are interested in whether PC contributes to the organization being perceived as ethical, just, and fair in a service recovery setting after a service failure. In other words, we study whether customers perceive the "doing good" as sufficient compensation for their negative service experience. When customers do not perceive being responsible to the society as important (so-called Consumer Social Responsibility; Vitell 2015), PC will never function as CSR engagement. In Experiments 2A and $2 \mathrm{~B}$, we researched the effects of receiving PC (with and without choice of charitable cause), no compensation, and tangible compensation on distributive justice, procedural justice, and post-recovery satisfaction.

In all our empirical studies, we used experimental vignette designs. Vignette studies are commonly used in CSR research (e.g., Alexander 2002; Bolton and Mattila 2015; Folse et al. 2010; Howie et al. 2015; Robinson et al. 2015). This technique is appropriate and therefore often used to investigate emotional situations (e.g., Barkworth and Murphy 2015; Schoefer and Ennew 2005; Van Doorn et al. 2012). Vignette studies have been used in similar service failure situations as in our research (Ohtsubo and Watanabe 2009; Thomassen et al. 2017) and are seen as having several advantages. Vignette studies supply standard and homogeneous stimuli to all respondents. This enhances internal validity and measurement reliability, eases replication, and improves construct validity by focusing respondents' attention upon specific features of the hypotheses (Wason et al. 2002). They also enable the investigation of scenarios that occur infrequently (Schoefer and Ennew 2005), as well as saving time by summarizing events that might, otherwise, unfold over a long period. Furthermore, instead adopting a random sampling approach would result in only a small number of respondents with relevant, but often different, experiences.

\section{Study 1: Signaling Effects of Promising Prosocial Compensation}

Signaling theory (Spence 1974) has been applied in many fields including finance, strategic management, corporate governance, human resource management, and marketing (Connelly et al. 2011) and has received infrequent, but growing, attention in the CSR and business ethics literature (Zerbini 2017). Signaling theory is concerned with situations in which customers have limited information about intangible aspects such as corporate CSR engagement (Zerbini 2017) and service quality (Erevelles et al. 2001; Roggeveen et al. 2014) than the organization has itself. This can lead to existing and potential customers having an incorrect perception of the organization. Signaling theory states that customers' perceptions can be affected by both intrinsic and extrinsic cues. Customers use extrinsic cues, such as advertisements about CSR practices, to identify ethical businesses, and distinguish them from the unethical ones (Zerbini 2017). In this way, investing in charitable causes and communicating this fact can signal that a company is sociably responsible. Other extrinsic cues such as third-party ratings, warranties (Zerbini 2017), codes of ethics (Colwell et al. 2011), and service guarantees (Ostrom and Iacobucci 1998) are similarly used to influence customers' perceptions. 
In this study, we investigate whether explicitly communicating the promise to offer $\mathrm{PC}$ has a positive signaling effect on CSR image. We also investigate the effects of PC on corporate image, perceived organizational credibility, and the behavioral WOM-intent.

Prosocial compensation can come in various guises, with either the supplier or the recipient of the unsatisfactory goods or services determining the charitable cause to which the compensation will be given. When customers have the possibility to choose the beneficiary, they may not only perceive the company as more ethically credible, they may also be more likely to perceive it as more socially responsible (Howie et al. 2015).

\section{CSR Image}

CSR image can, in general, be defined as the customers' perceptions of corporate responses to general social concerns held by all stakeholder groups (based on Pérez and del Bosque 2013a). It is important to distinguish between CSR image and the more general corporate image because research shows that a good CSR image contributes to corporate success since it can function as an important differentiating factor (e.g., Cantrell et al. 2015; Carroll and Shabana 2010; Gautier and Pache 2015; Kiessling et al. 2016) by increasing credibility, likeability, trustworthiness, and positive attitudes towards the company (Aaker 1996; Howie et al. 2015; Pérez and del Bosque 2013b). This could lead to an increase in satisfaction (Bolton and Mattila 2015; Pérez et al. 2013; Pérez and del Bosque 2015), which is important for both companies and public organizations.

Research on the effects of specific CSR practices shows the positive effects of cause-related marketing (Chernev and Blair 2015; Howie et al. 2015) and corporate volunteering (Plewa et al. 2015) on CSR image. Although the effects of PC on CSR image have not been investigated, we would expect, in line with the findings on cause-related marketing and corporate volunteering, that promising to offer PC after a service failure will have a more positive impact on CSR image than promising no or tangible compensation. In line with research on cause-related marketing (Howie et al. 2015), we also hypothesize that offering a choice positively affects CSR image. This leads to our first set of hypotheses:

H1a Promising to offer PC after a service failure leads to a more positive CSR image than not promising any compensation.

H1b Promising to offer PC after a service failure leads to a more positive CSR image than promising tangible compensation.
H1c Promising to offer PC with the cause determined by the customer leads to a more positive CSR image than when the cause is predetermined by the service provider.

\section{Corporate Image}

Corporate image is a customer's global evaluation of their attitudes and perceptions towards a company (Groza et al. 2011; Pfau et al. 2008). Possible dimensions include negative or positive, favorable or unfavorable, and bad or good (Aggarwal 2004; Groza et al. 2011). CSR practices build relational corporate assets such as an appealing and more positive corporate image (Hur et al. 2014; Kiessling et al. 2016; Pfau et al. 2008; Wood 2010) that enables companies to increase customer loyalty in the form of repurchase and recommendation behavior (Pérez and del Bosque 2015; Zerbini 2017). Here, the literature does not offer any clues as to whether CSR-related compensation would lead to better evaluations than more tangible compensation. However, research on corporate philanthropy practices shows that cause-related marketing campaigns (Kang and Hustvedt 2014; Varadarajan and Menon 1988), employee volunteering (Plewa et al. 2015), and donations (Cantrell et al. 2015) do have positive effects on corporate image. In addition, research into the effect of offering service guarantees has shown that this practice also has positive effects on corporate image (Roggeveen et al. 2014). However, the effects of PC on corporate image have not yet been researched.

\section{Credibility}

Corporate credibility is the customers' perceptions of the company's trustworthiness. From a CSR perspective, trust is the customers' expectations and perceptions of socially responsible or ethically justifiable corporate behavior (Hur et al. 2014). In the context of our research, credibility is the customers' belief and confidence that a company will act in the best interests of its customers and keep its promises (Hur et al. 2014; Kang and Hustvedt 2014). Positive corporate social behavior enhances customers' perceptions of an organization's credibility and trustworthiness (Hur et al. 2014; Pérez and del Bosque 2013b; Pfau et al. 2008). Practices such as sponsorship and cause-related marketing campaigns enhance corporate credibility (Kim and Choi 2007; Pérez and del Bosque 2013b). Communicating the offering of a service guarantee has similar positive effects on perceived credibility (Erevelles et al. 2001; McDougall et al. 1998; Ostrom and Iacobucci 1998). A high level of corporate credibility leads to customers forming a positive attitude towards a company and increases their loyalty towards the company (Kang and Hustvedt 2014; Pérez and del Bosque 2013b). 


\section{WOM-Intent}

WOM-intent, also referred to as willingness to recommend, is, in general terms, the behavioral intention to informally communicate one's evaluations of goods and services (Anderson 1998). WOM-intent can be negative in the forms of warning friends or others, taking legal action, or complaining to consumer agencies (Ingram et al. 2005). In this study, we focus on positive WOM-intent. Specifically where this study involves public services, WOM-intent is defined as the customers' intention to talk positively about an organization and defend it in situations where there is negative WOM. Research shows that both CSR practices (Kang and Hustvedt 2014) and communicating a service guarantee (Hocutt and Bowers 2005) have positive effects on WOM-intent.

Although the effects of promising to offer PC after a service failure on corporate image, credibility, and WOM-intent have not been previously studied, we would expect, based on the literature discussed above, that promising to offer PC will have a more positive effect on these variables than not promising any compensation (H2a). Given that both tangible and prosocial forms of compensation are perceived as costly for an organization, we hypothesize that PC will have similar effects as tangible compensation (H2b) on these variables. Finally, in line with research on cause-related marketing (e.g., Grau and Folse 2007; Howie et al. 2015; Robinson et al. 2012), we expect that offering PC with a choice of beneficiary will lead to a more positive corporate image, credibility and WOM-intent than when the beneficiary is predetermined $(\mathrm{H} 2 \mathrm{c})$.

H2a Promising to offer PC after a service failure leads to a more positive corporate image, higher credibility, and greater WOM-intent than when compensation is not promised.

H2b Promising to offer PC after a service failure has a similar effect on corporate image, credibility, and WOM-intent as offering tangible compensation.

H2c Promising to offer PC to a beneficiary of the customer's choosing leads to a more positive corporate image, higher credibility and WOM-intent than PC with a predetermined beneficiary.

\section{Sector}

We tested our hypotheses within both the public and private sectors to broaden the generalizability of our findings. Depending on the sector and industry, CSR practices can have different signaling effects on potential customers' evaluations (Pérez and del Bosque 2015; Strahilevitz and
Myers 1998). This could also be the case with PC. Furthermore, a service guarantee, the corresponding compensation, and in our case PC, should align with the image of the organization if it is to be effective (Marmorstein et al. 2001; Roggeveen et al. 2014). For example, the image people have of non-profit organizations is of being warmer but less professional than that of for-profit organizations (Aaker et al. 2010). Given that public organizations do not have a profit-driven focus, customers might also perceive public organizations as less professional than for-profit companies. Another factor is that public organizations are funded by collective means such as income tax revenues. Research on service guarantee compensation among passengers of Stockholm's public transport network (Björlin Lidén and Edvardsson 2003) showed that the public context leads to other additional compensation requirements such as being fair to customers and the careful use of taxpayers' money. In this sense, customers could regard it as less appropriate for public organizations to be spending money on compensating for service failures (Van de Walle 2016). However, in direct exchange situations, where customers pay for a public service, their money is directly related to the value they receive (Alford 2002). In such situations, there may well be many similarities in customers' evaluations of public and private services. Finally, offering compensation for poor service is relatively uncommon in public services compared with private services (Van de Walle 2016); people generally do not expect public organizations to compensate them for their service failures.

\section{Method}

\section{Participants and Design}

Experiment 1 was designed to test the signaling effects of PC on customers. A total of 603 US citizens ( $44.3 \%$ female; $\left.M_{\text {age }}=36.7 ; S D=10.96\right)$ participated through a digital webbased questionnaire (Qualtrics) using the online MTurk platform. They were randomly assigned to one of our four compensation conditions explained in the form of a service guarantee, and to one of two sectoral scenarios in a betweensubjects factorial design. The four guarantee options were no compensation, gift voucher, PC to a predetermined fixed cause, or PC to a cause of the customer's choosing each with two sectoral options (internet store, governmental visa organization).

\section{Procedure and Dependent Variables}

An internet store was used to represent a private organization, and a governmental visa organization as a public organization. Products were selected that would be 
relevant to the real-life experiences of the participants. Participants in the private sector scenario learned that they were looking at the website of the only internet store selling a specific product they wanted to buy. The public scenario participants learned they were planning to go to a foreign country and, therefore, needed to order a travel visa from the online website of the relevant governmental organization. Participants were each presented with one of these scenarios (private or public) and with one of the four service guarantees. Participants were asked to imagine themselves in the role of the potential customer in the encounter and to think about how they would evaluate the given situation. In the scenario where no compensation was offered, the organization promised: 'Friendly and efficient service. Whatever we do, we keep our promises, guaranteed! If not, we'll apologize and fix the problem.' In the three compensation scenarios, depending on the type of compensation, an additional line stated: 'You'll also receive a personal gift voucher worth 5 dollar/we will donate 5 dollar to a fixed cause/we will donate 5 dollar to a cause of your own choice.'

After reading their scenario, participants were asked to give their opinion on four dependent variables (see Appendix in Table 4 for all the items). In order for the items to fit with the scenarios, we used a four-item scale for CSR image ( $\alpha=0.94)$ combining two items used by Grohmann and Bodur (2015) and by Wagner et al. (2009) with two items used by Brown and Dacin (1997), Folse et al. (2010) and Howie et al. (2015). For example, we asked participants whether they thought the organization had a legitimate interest in improving society. To measure corporate image, we used a four-item scale $(\alpha=0.97)$ with, for example, the participant asked to rank the organization on a seven-point scale from unfavorable to favorable (cf. Aggarwal 2004; Groza et al. 2011). For credibility, in order to fit the scenario, an adapted four-item scale $(\alpha=0.81)$ was based on scales used by McDougall et al. (1998) and Ostrom and Iacobucci (1998). For example, we asked if the respondent would feel confident in dealing with the organization. Many scales measuring WOM-intent, including the intention to refer an organization, have been developed for private settings. To also measure WOM-intent in a public setting we developed a new scale including two items on whether participants would say positive things about the organization and whether they would argue against people saying negative things about that organization $(\alpha=0.77)$. Finally, and mainly for exploratory reasons, we also measured the effects on warmth, competence, and skepticism to investigate possible moderating effects of the sector. However, since no significant differences in the signaling effects of PC were found between the two sectors (see Results section below), we have not provided further information on these three dependent variables. Following questions concerning gender, age, and nationality, we asked participants to judge the realism of the scenario using a single item (cf. Magnini et al. 2007). In addition, at the end of the questionnaire, we presented three manipulation checks to ensure that participants had grasped their specific scenario in terms of the sector, the communication of a service guarantee, and the compensation promised. Finally, we used an adapted version of the instructional manipulation check question (cf. Oppenheimer et al. 2009) to assess whether participants were properly reading and understanding the questions.

\section{Results and Discussion}

\section{Manipulation Checks and Control Variables}

The criteria we applied led to the exclusion of 22 of the 625 participants who failed the instructional manipulation check and/or two or three of the manipulation checks. We further compared the results with and without those participants who failed one of the manipulation checks and, as the results showed similar patterns, we included those participants with only one failed check.

We ran a $4 \times 2$ ANOVA on the perceived realism of each scenario to check whether the scenarios were equally realistic. This indicated a significant Compensation effect: $F(3,595)=19.88, p=.000\left(M_{\mathrm{NC}}=5.44, S D=1.38\right.$; $M_{\mathrm{GV}}=4.77, S D=1.74 ; M_{\mathrm{FC}}=4.27, S D=1.70 ; M_{\mathrm{CCC}}=4.11$, $S D=1.88)$. The analysis also showed a significant Sector effect: $F(1,595)=31.60, p=0.000\left(M_{\text {internet store }}=5.03\right.$, $\left.S D=1.56 ; M_{\text {visa }}=4.26, S D=1.85\right)$. We considered this further in order to rule out differences in perceived realism as an alternative driver for the effects found in the general ANOVAs (see later results). In this check, we were unable to run an ANCOVA with realism as a covariate (since the covariate was not independent of the treatment conditions: cf. Field 2013; Gerber and Green 2012), nor could we use PROCESS analyses (Hayes 2009) given our multi-categorical predictor. Therefore, we used regression analyses including realism and the four dummy variables indicating Sector and Compensation conditions (with No compensation being the reference group) and excluding a constant in the equation to rule out realism as an alternative driver of Compensation effects on the dependent variables. Results showed that realism was partially mediating the effects (realism predicted our four DVs, $p<0.001)$. However, and more importantly, the effects of Compensation and Sector remained significant $(p$ 's $<0.05)$ when controlling for this partial mediator and showed the same pattern of effects as with the ANOVAs. As such, although realism was found to explain parts of the effects, it was not their only driver and, thus, cannot constitute an alternative explanation for our findings. Having resolved this issue, we can now continue to report the results 
Table 1 Means (SDs in parentheses) of the dependent variables depending on compensation type (Experiment 1)

\begin{tabular}{lllll}
\hline & No compensation (NC) & Gift voucher $(\mathrm{GV})$ & Fixed cause (FC) & $\begin{array}{l}\text { Customer's } \\
\text { chosen cause } \\
\text { (CCC) }\end{array}$ \\
\hline$N$ & 144 & 155 & 153 & 151 \\
CSR image & $4.62^{\mathrm{a}}(1.14)$ & $4.95^{\mathrm{a}}(1.13)$ & $5.37^{\mathrm{b}}(1.11)$ & $5.40^{\mathrm{b}}(1.20)$ \\
Corporate image & $5.41^{\mathrm{a}}(1.06)$ & $5.76^{\mathrm{b}}(0.90)$ & $5.73^{\mathrm{ab}}(1.09)$ & $5.86^{\mathrm{b}}(1.14)$ \\
Credibility & $4.52^{\mathrm{a}}(0.95)$ & $4.93^{\mathrm{b}}(0.99)$ & $4.99^{\mathrm{b}}(1.11)$ & $4.96^{\mathrm{b}}(1.18)$ \\
WOM-intent & $4.09^{\mathrm{a}}(1.26)$ & $4.67^{\mathrm{b}}(1.24)$ & $4.67^{\mathrm{b}}(1.35)$ & $4.71^{\mathrm{b}}(1.41)$ \\
\hline
\end{tabular}

Means with the same superscript (a or b) within a row are not significantly different from each other (Bonferroni, $p<0.05$ ) of the ANOVAs that include both the main and interaction effects.

\section{Main Dependent Variables}

A MANOVA with the four dependent variables yielded a significant main effect of Compensation, $\Lambda=0.89$, $F(12,1566.58)=6.19, p=0.000$. These variables are correlated significantly (r's vary between 0.62 and 0.76 , $p$ 's $<0.001$ ), but as $r$ 's $<0.90$ we can include all four in the MANOVA (cf. Tabachnick and Fidell 2001). Separate univariate ANOVAs on the outcome variables revealed significant Compensation effects on corporate image $(F(3,595)=4.80, p=0.003)$, credibility $(F(3,595)=6.28$, $p=0.000)$, WOM-intent $(F(3,595)=7.06, p=0.000)$ and CSR-image $(F(3,595)=15.13, p=0.000)$-see Appendix in Table 5. In order to test the hypotheses $1 \mathrm{a}, 1 \mathrm{~b}$ and 2 , we used specific post hoc Bonferroni analyses using pairwise comparisons of the dependent variables. The results are presented in Table 1. See Appendix in Table 6 for $M$ s and $S D$ s of all cell means.

In terms of CSR image, the results show that PC with either a fixed cause $(M=5.37, S D=1.11)$ or a cause of the customer's choosing $(M=5.40, S D=1.20)$ led to a significantly more positive CSR image than when no compensation was offered $(M=4.62, S D=1.14)$ (FC-NC: $p=0.000$; CCC-NC: $p=0.000)$. Results also showed that both types of PC led to a significantly more positive CSR image than a gift voucher $(M=4.95, S D=1.13)$; (FC-GV: $p=0.007$; $\mathrm{CCC}-\mathrm{GV}: p=0.003)$. In terms of corporate image, $\mathrm{PC}$ of the customer's choosing $(M=5.86, S D=1.14)$ led to a significantly more positive corporate image than no compensation $(M=5.41, S D=1.06)$; (CCC-NC: $p=0.002)$. However, PC with a fixed cause $(M=5.73, S D=1.09)$ resulted in a similar corporate image to no compensation (FC-NC: $p=0.066$ ). Both types of PC led to a similar corporate image as the promise of a gift voucher $(M=5.76, S D=0.90)$; $(\mathrm{FC}-\mathrm{GV}$ : $p=1.000$; CCC $-\mathrm{GV}: p=1.000)$. When it came to credibility, both types of $\mathrm{PC}\left(M_{\mathrm{FC}}=4.99, S D_{\mathrm{FC}}=1.11 ; M_{\mathrm{CCC}}=4.96\right.$, $\left.S D_{\mathrm{CCC}}=1.18\right)$ led to significantly more positive credibility than no compensation $(M=4.52, S D=0.95)$; $(\mathrm{FC}-\mathrm{NC}$ : $p=0.001 ;$ CCC $-\mathrm{NC}: p=0.003)$ and to similar credibility perceptions as when a gift voucher was on offer $(M=4.93$, $S D=0.99)$; (FC-GV: $p=1.000$; CCC-GV: $p=1.000)$. Finally, concerning WOM-intent, the results showed that both types of PC $\left(M_{\mathrm{FC}}=4.67, S D_{\mathrm{FC}}=1.35 ; M_{\mathrm{CCC}}=4.71\right.$, $\left.S D_{\mathrm{CCC}}=1.41\right)$ led to a significantly more positive WOMintent than no compensation $\left(M_{\mathrm{NC}}=4.09, S D_{\mathrm{NC}}=1.26\right)$; (FC-NC: $p=0.001$; CCC-NC: $p=0.000$ ), and to a similar WOM-intent as a gift voucher $(M=4.67, S D=1.24)$; (FC-GV: $p=1.000$; CCC-GV: $p=1.000$ ).

The analyses reported above combine both the private and public scenario data since the findings were broadly similar in individual analyses of the private and public settings. In more detail, although the MANOVA also yielded a significant effect of Sector, $\Lambda=0.98, F(4,592)=3.18$, $p=0.013$, subsequent separate univariate ANOVAs revealed non-significant effects of sector with only one exception: there was a significant main Sector effect on CSR image, $F(1,595)=6.21, p=0.013 ; M_{\text {internet store }}=4.97, S D=1.17$; $M_{\text {visa }}=5.20, S D=1.20$ (Appendices in Tables 5 and 6 contain all the results of all three experiments). More importantly, there were no interaction effects between Sector and Compensation ( $F$ 's $<1.86$, $p$ 's $>0.136$; see Table 1; Appendix in Table 5), indicating that there were no significant differences between the two sectors in the signaling effects of PC.

To summarize, H1a and $\mathrm{H} 1 \mathrm{~b}$ were confirmed in that PC leads to a more positive CSR image than no compensation or tangible compensation. We also hypothesized that PC leads to a more positive corporate image, credibility, and WOM-intent than not promising any compensation (H2a). Our results support this hypothesis with one exception: fixed cause PC did not have a more positive effect on corporate image than no compensation. In $\mathrm{H} 2 \mathrm{~b}$, we hypothesized that PC would lead to a similar corporate image, credibility, and WOM-intent as tangible compensation, and our results confirmed this. In $\mathrm{H} 1 \mathrm{c}$ and $\mathrm{H} 2 \mathrm{c}$, we hypothesized that $\mathrm{PC}$ with a choice of beneficiary would lead to more favorable evaluations than a fixed cause. Results failed to confirm this argument since there were no significant differences. Further, we found the effects to be similar in private and public settings. 


\section{Study 2: Justice Effects of Offering Prosocial Compensation}

CSR research on customer attitudes and behaviors has mainly focused on its impact on choice and preferences, and has largely ignored the context of the service provision (Bolton and Mattila 2015, p. 140). This includes those situations where something has gone wrong because of a service failure. In these cases, service recovery, the response a company makes to a service failure (Alexander 2002), has to support the corporate obligation to be just and fair to customers by recompensing the perceived loss (Mattila 2001). The aim of service recovery and offering compensation after a service failure is thus to restore perceived justice and restore the customer to a state of satisfaction (Mattila 2001).

Justice theory, also known as 'equity theory,' has not been widely used in the CSR literature (for some exceptions see e.g., Alexander 2002; Siu et al. 2013). However, justice theory is the dominant theory in the marketing and service management literature when addressing service recovery. Justice theory states that customers feel they have been fairly and ethically treated in a recovery situation when they perceive the recovery as balancing their loss. In any service failure encounter, companies need to develop ethical recovery strategies that avoid customers perceiving inequity. Customers consider three kinds of fairness in their evaluations (Homburg and Fürst 2005; Vázques-Casielles et al. 2010): distributive justice (the perceived fairness of the outcome), procedural justice (the perceived fairness of the corporate recovery policies and procedures), and interactional justice (the perceived fairness of treatment by employees).

$\mathrm{PC}$ is an intangible and psychological form of benefit that customers receive following a service failure. We argue that although PC does not provide tangible compensation in the form of a material benefit, such as a discount or a refund to the customer, customers receive value and equity from the act of giving. Consequently, PC could transform an inequitable exchange to an equitable one in a service recovery situation. This might in fact be considered a form of Consumer Social Responsibility (Vitell 2015; Pigors and Rockenbach 2016), as PC could appeal to customers' responsibility to act in the benefit of society. Indeed we know that people who donate to a cause may view themselves as good people, enhancing their self-esteem and happiness (e.g., Howie et al. 2015). Research addressing prosocial spending on charitable causes has illustrated that people who spend money on others, give gifts, or make charitable donations report greater happiness (Aknin et al. 2013; Dunn et al. 2008). The act of giving contributes to one's sense of being altruistic, empathic, socially responsible, agreeable, and influential (for an overview, see Bekkers and Wiepking 2011). Moreover, research on cause-related marketing shows that these campaigns can lead customers, apart from acquiring a product, to sense pleasure from donating to a good cause (Robinson et al. 2012; Strahilevitz and Myers 1998). In our study, we have researched the effects of PC on distributive justice, procedural justice, and post-recovery satisfaction while holding interactional justice constant (cf. Chrisafulli and Sing 2016).

Finally, research in other situations has shown that customers experience greater value and equity when they have the freedom to choose a cause (Mattila and Cranage 2005). For example, cause-related marketing campaigns in which customers can choose the charitable cause generally lead to more positive customer evaluations than campaigns with fixed causes (Howie et al. 2015; Robinson et al. 2012). These findings might be explained by 'cause importance' and 'personal involvement.' First, 'cause importance' is the degree to which customers find the cause personally relevant, with customers identifying with certain causes and considering some causes more relevant than others (Grau and Folse 2007; Howie et al. 2015). As such, the more important a cause is to the customer, the more likely they may be to sense outcome and distributive justice. Second, 'personal involvement' is the process of actively choosing and being involved in the donation procedure (Robinson et al. 2012). This act of opting for a specific cause and being part of the donation process could have positive effects on procedural justice.

\section{Distributive Justice}

Justice theory argues that a customer will perceive inequity when comparing their own outcome to investment ratio with that of another and finding a difference (Alexander 2002; Siu et al. 2013). Distributive justice is the perceived fairness of the outcome (Adams 1965; Homburg and Fürst 2005). Research shows that tangible forms of compensation have positive effects on perceived distributive justice (e.g., Wirtz and Mattila 2004; Schoefer and Ennew 2005). In a similar vein, we argue that offering PC will lead to more positive customer evaluations than where compensation is not provided (H3a). The question then arises as to whether PC can be as effective as tangible compensation in restoring distributive justice. We know that the strongest recovery effect occurs when the type of compensation represents a resource similar to the failure it is supposed to offset (Roschk and Gelbrich 2014). As an example, consider a customer who is informed that an ordered product is ready for collection and then spends 20 min going to the pick-up point only for the product to not be there. This failure to deliver could be seen as a monetary loss since the customer has spent time, energy, and money going to the pick-up point. Given the type of 
loss, we therefore hypothesize that prosocial compensation will lead to a less positive evaluation than would tangible compensation (H3b). Based on findings in cause-related marketing settings (Howie et al. 2015; Robinson et al. 2012), we further hypothesize that when customers can choose the cause themselves, and the 'cause importance' increases, their perception of the distributive justice will be more positive than when the cause is predetermined (H3c).

H3a Receiving PC after a service failure leads to a more positive sense of distributive justice than where no compensation is offered.

H3b Receiving PC after a service failure leads to a less positive evaluation of distributive justice than receiving tangible compensation.

H3C Receiving PC where the customer can choose the cause leads to a more positive sense of distributive justice than when the service provider has predetermined the cause.

\section{Procedural Justice}

Procedural justice is the perceived fairness of the corporate recovery policies and procedures (Homburg and Fürst 2005), and we were interested to compare the effects of the various compensation procedures on perceived procedural justice. In the no compensation scenario, no action is required from the customer. In the tangible compensation situation, such as being offered a gift voucher, the customer proactively receives the voucher. However, where PC is offered, more complex procedures (putting a card in a box, filling in a form) are required. These differences could lead to different evaluations. Research on causerelated marketing actions has shown that there is a negative relationship between the personal costs in terms of effort and time and a customer's willingness to participate in a campaign (Carroll and Shabana 2010). Research on prosocial behavior has similarly documented that personal costs negatively influence an individual's intentions to opt for prosocial behavior (Howie et al. 2015). If the offer of PC similarly requires active customer participation, then the associated personal costs will increase. Therefore, we hypothesize that the simpler and more transparent procedures of no compensation ( $\mathrm{H} 4 \mathrm{a}$ ) and the provision of a gift voucher $(\mathrm{H} 4 \mathrm{~b})$ will result in higher procedural justice than offering prosocial compensation.

Research on cause-related marketing shows that 'personal involvement' affects customers' evaluations. Having a choice enhances a customer's personal role in helping the cause (Robinson et al. 2012) and the feeling of personal responsibility (Mattila and Cranage 2005). Being involved in the donation procedure by choosing the cause to support increases customers' perceived procedural justice (Robinson et al. 2012). Consequently, being able to choose a specific cause when offered PC should lead to a more positive evaluation of procedural justice than when the cause is predetermined $(\mathrm{H} 4 \mathrm{c})$.

H4a Receiving PC after a service failure results in less procedural justice than when compensation is not offered.

H4b Receiving PC after a service failure results in less procedural justice than when tangible compensation is received.

H4c Receiving PC with a choice of good cause leads to a more positive sense of procedural justice than when the cause is predetermined.

\section{Post-recovery Satisfaction}

Customer satisfaction in general can be defined as their evaluation of the post-consumption experience of products or services based on their overall purchase and consumption experiences (based on Anderson et al. 2004; Luo and Bhattacharya 2006). Customer satisfaction has been regarded as a pivotal element in maintaining long-term customer relationships and increasing corporate value (e.g., Luo and Bhattacharya 2006). CSR efforts have been shown to have a positive effect on customer satisfaction (Kang and Hustvedt 2014; Luo and Bhattacharya 2006; Pérez and del Bosque 2013a). Research on the relationship between CSR and service failures has found that CSR has a buffering role in the negative impact of failures on customer satisfaction (Bolton and Mattila 2015). Our research focuses on post-recovery satisfaction, which we define as a customer's evaluation of a post-failure recovery situation.

When customers encounter a service failure, a crucial challenge is how to restore their satisfaction (Siu et al. 2013). Expectancy disconfirmation theory (Oliver 1993) states that differences between recovery expectations and experiences can lead to positive or negative disconfirmations, which subsequently influence post-recovery satisfaction. Customers have ethical expectations about the fairness and rightness of the recovery. In effect, people have certain standards against which they judge an organization's corporate recovery actions and the way it behaves morally (Ingram et al. 2005; Magnini et al. 2007). The perceived justice of the recovery actions provokes the cognitive evaluation of postrecovery satisfaction. Service recovery research has shown that receiving tangible compensation has a positive effect on post-recovery satisfaction (e.g., Del Rìo-Lanza et al. 2009; Schoefer and Ennew 2005; Thomassen et al. 2017; Wirtz and Mattila 2004). 
Based on the literature (e.g., Del Rì-Lanza et al. 2009; Kang and Hustvedt 2014; Luo and Bhattacharya 2006; Pérez and del Bosque 2013a), we would expect the receipt of PC after a service failure to have a more positive effect on post-recovery satisfaction than not being offered any compensation (H5a). In line with our earlier reasoning, we further hypothesize that PC will lead to less positive postrecovery satisfaction than receiving tangible compensation (H5b), and that PC to a cause of the customer's choosing leads to more positive post-recovery satisfaction ratings than when the cause is determined by the service provider (H5c).

H5a Receiving PC after a service failure leads to more positive post-recovery satisfaction than if no compensation is offered.

H5b Receiving PC after a service failure leads to lower postrecovery satisfaction than receiving tangible compensation.

H5C Receiving PC where the cause is chosen by the customer leads to more positive post-recovery satisfaction than when the cause is predetermined by the service provider.

\section{Sector}

As in Experiment 1, we tested our hypotheses within the public and private sectors to broaden the generalizability of our findings. Many public services are indirectly funded through taxpayers' money, although specific products such as visas and driving licenses might be paid for directly by citizens acting as customers. In order to use comparable public and private service situations we simulated such a situation. That is, in both the public and private sector scenarios, there was a direct exchange situation in which a customer's money is directly related to the value they receive (Alford 2002). Therefore, after a service failure, one might expect similar customer evaluations in both scenarios.

\section{Method Experiment 2A}

In testing our hypotheses, we first conducted a relatively small experiment in a research laboratory that compared the effects of PC with those of tangible compensation (Hypotheses $3 b, 3 c, 4 b, 4 c, 5 b$, and 5c). Later, in Experiment 2B, we tested all the hypotheses.

\section{Participants and Design}

In total, 148 Dutch undergraduate students (45.8\% female; $\left.M_{\text {age }}=21.0 ; S D=2.33\right)$ participated, for which they earned course credits. They were randomly assigned to one condition of an experiment with a 3 (compensation ${ }^{1}$ : gift voucher, $\mathrm{PC}$ with a fixed cause, $\mathrm{PC}$ of customer's choosing) $\times 2$ ( $\mathrm{sec}$ tor: private, public) between-subjects factorial design. Computers gave all the instructions for the participants.

\section{Procedure and Dependent Variables}

Similar to Experiment 1, an internet store was used to represent a private organization. However, in order to broaden insights into the effects of PC in public settings, we changed from a governmental visa organization to a Dutch municipality and the task to issuing driving licenses. Both the public and private scenarios would be relevant to Dutch undergraduate students. Participants were informed that, in the private scenario, they had ordered a product from the only internet store that sold a specific product for 40 euro. In the municipality scenario, participants were informed that they had requested a new driving license that again cost 40 euro. Participants then receive a message that the product/license is ready for collection (about a 20-min drive from home). In both scenarios, the customer than goes to the collection point and is served by an employee. They are then informed by the employee that the product/license is not yet available as it has not been delivered by the supplier, and that it will be available the next day. Given that we had to use different types of product, we wanted to ensure that this did not lead to a difference in the perceived severity of the service failure. Therefore, we asked participants to indicate the perceived severity of the service failure (cf. Mattila 2001).

The scenario continued with participants seeing, behind the employees' desk, a large poster stating the service guarantee: 'Whatever we do, we keep our promises, guaranteed!' and in addition, depending on which scenario they had been allocated: 'If not you'll receive a personal gift voucher worth 5 euro/we will donate 5 euro to a fixed cause/we will donate 5 euro to a cause of your choosing.' This was followed by an apology by the employee and the immediate offering of compensation. Depending on the scenario, this amounted to a gift voucher, placing a card in a box ( $\mathrm{PC}$ with predetermined cause), or asking the customer for their chosen

\footnotetext{
${ }^{1}$ Experiments $2 \mathrm{~A}$ and $2 \mathrm{~B}$ also contained an additional double deviation condition. Under this condition, people were initially promised compensation but following a failure (the first deviation) were not offered one (a second deviation). Since this article focuses on the effects of prosocial compensation, it is not relevant to compare the effects of PC with those of a double deviation condition here. However, we would like to note that the results for the double deviation condition were similar to previously reported effects (e.g., CasadoDíaz and Nicolau-Gonzálbez 2009; Thomassen et al. 2017): that it leads to lower levels of perceived justice and post-recovery satisfaction than not promising and not offering compensation.
} 
Table 2 Means $(S D$ s in parentheses) for the dependent variables by compensation type (Experiment 2A)

\begin{tabular}{llll}
\hline & Gift voucher $(\mathrm{GV})$ & Fixed cause (FC) & $\begin{array}{l}\text { Customer's } \\
\text { chosen cause } \\
\text { (CCC) }\end{array}$ \\
\hline$N$ & 48 & 48 & 52 \\
Distributive justice & $4.31^{\mathrm{a}}(1.28)$ & $3.08^{\mathrm{b}}(1.32)$ & $3.40^{\mathrm{b}}(1.28)$ \\
Procedural justice & $5.14^{\mathrm{a}}(1.44)$ & $3.91^{\mathrm{b}}(1.42)$ & $4.43^{\mathrm{b}}(1.54)$ \\
Post-recovery satisfaction & $3.25^{\mathrm{a}}(1.39)$ & $2.60^{\mathrm{b}}(1.18)$ & $2.96^{\mathrm{ab}}(1.28)$ \\
\hline
\end{tabular}

Means sharing the same superscript (a or b) within a row are not significantly different from each other (Bonferroni, $p<0.05$ ) cause. The compensation was set at 5 euro and, as such, was unrelated to, nor fully compensated for, the inconvenience caused. This was because being overly generous following a service failure may lead customers to question the reasons behind the over-generosity of a public organization and to doubt the sincerity and credibility of the service guarantee (McQuilken et al. 2013). At the end of this interaction, participants were thanked and asked by the employee to return the next day to collect the product/license. Participants were then asked to imagine themselves outside the building and reflecting on the situation.

Next, participants were asked to complete our questionnaire (for an overview of all the items: see Appendix in Table 4). For distributive justice, we used a three-item scale from Lii and Lee (2012) adapted for the specific scenario $(\alpha=0.80)$. A sample item being, 'The compensation for the inconvenience is fair.' Scales used to measure procedural justice are often based on situations where customers had to complain and, in our scenarios, this was not the case. Therefore, in order to fit our situation, we developed a new threeitem scale for procedural justice $(\alpha=0.83)$ with a sample item being: 'The organization used a good procedure to solve my problem.' Given that the manner in which employees interacted with customers in this recovery situation was fixed (for instance, they always apologized), we did not include interactional justice as a dependent variable (cf. Crisafulli and Singh 2016; Thomassen et al. 2017). For post-recovery satisfaction, we used a three-item scale $(\alpha=0.83)$ that had been applied by McCollough et al. (2000), and later by Huang and Lin (2011), with an example question being: 'Overall, how satisfied or dissatisfied did this experience make you feel?' Further, we wanted to control for perceived realism and, therefore, asked participants to indicate the perceived realism of their scenario (cf. Magnini et al. 2007). Finally, we asked for the demographics of the participant (age, gender, and nationality). The questionnaire ended with four manipulation checks to verify whether participants had grasped the specific elements of their scenario.

\section{Results and Discussion Experiment 2A}

\section{Manipulation Checks and Control Variables}

Five of the 153 respondents were excluded from the analysis for failing two or more of the manipulation checks. As in Experiment 1, we compared the results with and without those participants who failed a single manipulation checks and the results again showed similar patterns and therefore these participants were included. This resulted in 148 valid cases for the subsequent analysis. A one-way ANOVA with Sector as the only independent variable (as Compensation type was only manipulated after this question had been answered) on the severity of the service failure indicated that there was no significant Sector effect: $F(1,141)=0.001, p=0.974\left(M_{\text {internet store }}=5.71 ; S D=1.42\right.$; $M_{\text {municipality }}=5.70 ; S D=1.43$ ). A full factorial ANOVA on perceived realism similarly failed to find a significant Sector effect: $F(1,142)=1.80, p=0.182\left(M_{\text {internet store }}=4.32\right.$; $\left.S D=1.68 ; M_{\text {municipality }}=4.11 ; S D=1.84\right)$, and no significant Compensation effect: $F(2,142)=2.78, p=0.065$ ( $M_{\text {gift voucher }}=4.60 ; S D=1.77 ; M_{\text {fixed cause }}=4.15 ; S D=1.70$; $\left.M_{\text {customer's chosen cause }}=3.92 ; S D=1.75\right)$. There was also no significant interaction effect. As such, we can rule out perceived severity and perceived realism as alternative drivers of Sector or Compensation effects.

\section{Main Dependent Variables}

A MANOVA with the three dependent variables yielded a significant main effect of Compensation: $\Lambda=0.81, F(6$, $280)=5.25, p=0.000$. Separate univariate ANOVAs on the outcome variables revealed significant Compensation effects on distributive justice $(F(2,142)=13.10, p=0.000)$, procedural justice $(F(2,142)=9.41, p=0.000)$, and post-recovery satisfaction $(F(2,142)=3.09, p=0.049)$. As in Experiment 1 , in order to test the hypotheses, we employed specific post hoc Bonferroni analyses using pairwise comparisons of the dependent variables. The main results are presented in Table 2, and the means and standard deviations for all 
the compensation types by sector are included Appendix in Table 6.

In terms of distributive justice, tangible compensation, here a gift voucher, $(M=4.31, S D=1.28)$ led to a significantly higher perception of distributive justice than both types of $\mathrm{PC}\left(M_{\mathrm{FC}}=3.08, S D_{\mathrm{FC}}=1.32 ; M_{\mathrm{CCC}}=3.40\right.$, $\left.S D_{\mathrm{CCC}}=1.28\right)$; (GV-FC: $p=0.000$; GV-CCC: $\left.p=0.000\right)$. There was no significant difference in distributive justice between the two forms of PC, (CCC-FC: $p=1.000)$. Again with procedural justice, tangible compensation $(M=5.14$, $S D=1.44$ ) led to a significantly higher perception of procedural justice than both types of $\mathrm{PC}\left(M_{\mathrm{FC}}=3.91, S D_{\mathrm{FC}}=1.42\right.$; $\left.M_{\mathrm{CCC}}=4.43, S D_{\mathrm{CCC}}=1.54\right)$; (GV-FC: $p=0.000 ;$ GV-CCC: $p=0.015)$. and there was no significant difference between the two forms of PC (CCC-FC: $p=0.461)$. Finally, for postrecovery satisfaction, tangible compensation $(M=3.25$, $S D=1.39$ ) once again led to significantly higher postrecovery satisfaction than $\mathrm{PC}$ with a fixed cause $\left(M_{\mathrm{FC}}=2.60\right.$, $\left.S D_{\mathrm{FC}}=1.18\right)$; GV-FC: $p=0.043$; but PC with a customer's chosen cause was similarly effective as tangible compensation in creating post-recovery satisfaction $\left(M_{\mathrm{CCC}}=2.96\right.$, $\left.S D_{\mathrm{CCC}}=1.28\right)$; GV-CCC: $p=0.439$. However, PC with a choice of cause led to similar post-recovery satisfaction as that with a fixed cause (CCC-FC: $p=0.929)$. As in Experiment 1, the MANOVA failed to identify any significant Sector effects $(\mathrm{A}=0.98, F(3,140)=1.11, p=.346)$ or interaction effects between Compensation and Sector $(\Lambda=0.98$, $F(6,280)=0.44, p=0.851)$. All the Means and Standard Deviations for each compensation type-sector combination are included Appendix in Table 6.

To summarize, the results of Experiment 2A, indicate that both types of PC lead to significantly lower distributive (H3b) and procedural justice (H4b) than tangible compensation. This is also true for post-recovery satisfaction when comparing tangible compensation and PC with a fixed cause. However, PC with the customer choosing the cause led to similar postrecovery satisfaction as offering a gift voucher $(\mathrm{H} 5 \mathrm{~b})$. Further, there were no significant differences in the evaluations of the two types of $\mathrm{PC}(\mathrm{H} 3 \mathrm{c}, \mathrm{H} 4 \mathrm{c}$, and $\mathrm{H} 5 \mathrm{c})$. There were also no significant differences between the two sectors.

\section{Method Experiment 2B}

Experiment 2A showed that, generally, tangible compensation results in higher perceived justice and satisfaction than PC. The one exception being that PC where the customer chooses the cause scores equally well for post-recovery satisfaction. In Experiment 2B, we added a control condition in which no promise of compensation was made, and no compensation given. This was in order to test whether PC had positive effects compared with not offering compensation (Hypotheses 3a, 4a, and 5a). In this experiment, we expected that although tangible compensation would still yield higher perceptions of justice and satisfaction than PC (as found in Experiment 2A), that $\mathrm{PC}$ would have a compensatory function and, thus, would work better after a service failure than no compensation at all.

Further, in Experiment 2A, we had used a rather small sample of Dutch students. In order to increase the power of our data, we used a larger sample, this time mainly US citizens, in Experiment 2B. In Experiment 2A, we had found that Sector did not influence the perceived severity of the service failure, suggesting there were no concerns regarding the manipulation we had applied. However, we had asked the control question to test this prior to introducing the Compensation manipulation, and we were concerned that this could have influenced subsequent interpretation of the scenarios. Therefore, in Experiment 2B we asked this control question after the introduction of both manipulations. We expected to find no effect of Sector on perceived severity (cf. Experiment 2A), which would again suggest that the product type did not confound with setting. However, one could expect that people find a service failure especially important when perceived procedural and distributive justice is low, i.e., when there is no compensation.

\section{Participants}

In total, 633 people participated in this experiment, of which 596 people (43\% female; $M_{\text {age }}=36.6 ; S D=11.36$ ) satisfied the control criteria and were included in the analyses (see Results section). Of these, $98.2 \%$ lived in the United States, $1.6 \%$ in Canada, and $0.2 \%$ in other countries. They participated through a digital web-based questionnaire (Qualtrics) using the online MTurk platform.

\section{Design, Procedure, and Dependent Variables}

Experiment 2B was identical to Experiment 2A apart from three aspects. First, although participants still read that the product was not there yet, received an apology, and were asked to return the next day, no reference was made to any service guarantee or compensation. Second, since the distribution of driving licenses is organized differently in the US to the Netherlands, we could not use the issuance of driving licenses as our public sector scenario. Therefore, similar to Experiment 1 , we used a governmental visa organization for the public setting. Third, and again similar to Experiment 1, we applied three manipulation checks and included one instructional manipulation check question (cf. Oppenheimer et al. 2009). However, this time, the questions on the perceived severity and perceived realism of our control variables were asked after the manipulation of the independent variables. The same dependent variables were used in this third experiment as in Experiment 2A: distributive justice $(\alpha=0.90)$, procedural justice $(\alpha=0.84)$ and post-recovery satisfaction $(\alpha=0.96)$. 


\section{Results and Discussion Experiment 2B}

\section{Manipulation Checks and Control Variables}

We used the same criteria for exclusion of participants as in Experiment 1 with an MTurk panel. This resulted in excluding 37 of the 633 respondents, leading to 596 usable cases. The ANOVA on the perceived realism of the scenarios indicated that only Compensation had a significant effect: $F(3,588)=52.87$, $p=0.000\left(M_{\mathrm{NC}}=5.97 ; S D=1.16 ; M_{\mathrm{GV}}=5.24 ; S D=1.81\right.$; $\left.M_{\mathrm{CCC}}=4.29 ; S D=1.57 ; M_{\mathrm{FC}}=3.81 ; S D=1.80\right)$. As in Experiment 1 , we used regression analyses, including Realism and the four dummy variables that indicated the Sector and Compensation condition (with No compensation forming the reference group), and excluding a constant in the equation to rule out Realism as an alternative driver of the Compensation effects on the dependent variables. Our results showed that Realism significantly predicted procedural justice $(p=0.000)$ and postrecovery satisfaction $(p=0.000)$, and was a marginally significant predictor of distributive justice $(p=0.059)$. More importantly, the effects of all the dummy variables on all three DVs remained significant $(p$ 's $=0.000)$, indicating that realism was only partially driving the Compensation effects. Therefore, we continued testing our hypotheses using ANOVAs.

A full factorial ANOVA on the perceived severity of the service failure found no main Sector effect, $F(3,588)=2.26, p=0.133$, nor a significant interaction effect, $F(3,588)=0.30, p=0.825$. This suggests that the difference in products did not influence the perceived severity of the service failure. Thus, there was no confounding effect due to our sector manipulation. We did find that Compensation had a significant main effect, $F(3,588)=3.70, p=0.012$, indicating that participants perceived the service failure as more important when there was no compensation $\left(M_{\mathrm{NC}}=5.53, S D=1.25\right)$ compared to when there was some form of compensation $\left(M_{\mathrm{GV}}=5.10, S D=1.33 ; M_{\mathrm{CCC}}=5.16, S D=1.39\right.$; $M_{\mathrm{FC}}=5.08, S D=1.38$ ). This broad finding is in line with the findings on justice and satisfaction as outlined below.

\section{Main Dependent Variables}

A MANOVA including the three dependent variables indicated that Compensation had a significant main effect, $\Lambda=0.79, F(6,1426.32)=16.09, p=0.000$. Separate univariate ANOVAs on the outcome variables revealed significant Compensation effects on distributive justice $(F(3,588)=38.02, p=0.000)$, on procedural justice $(F(3,588)=46.62, p=0.000)$, and on post-recovery satisfaction $(F(3,588)=36.71, p=0.000)$-see Appendix in Table 5 . Comparing the results of the private and public settings shows that there was virtually no Sector effect, $\Lambda=1.00, F(3$, 586) $=0.79, p=0.506$, nor interaction effect involving Sector, $\Lambda=0.98, F(9,1426.32)=1.10, p=.360$. The one exception was that we found a marginally significant interaction effect in the procedural justice ANOVA, $F(3,588)=2.54$, $p=0.056$. We will discuss this further when we present the specific findings on procedural justice.

When it came to distributive justice, $\mathrm{PC}$ with both fixed $\left(M_{\mathrm{FC}}=3.25, S D_{\mathrm{FC}}=1.50\right)$ and customer's chosen causes $\left(M_{\mathrm{CCC}}=3.47, S D_{\mathrm{CCC}}=1.62\right)$ led to significantly higher distributive justice than not offering compensation $\left(M_{\mathrm{NC}}=2.13\right.$, $\left.S D_{\mathrm{NC}}=1.17\right) ;(\mathrm{FC}-\mathrm{NC}: p=0.000 ; \mathrm{CCC}-\mathrm{NC}: p=0.000)(\mathrm{see}$ Table 3). Tangible compensation $\left(M_{\mathrm{GV}}=3.88, S D_{\mathrm{GV}}=1.57\right)$ led to significantly higher positive distributive justice than fixed cause PC (GV-FC: $p=0.001$ ) but to similar distributive justice as $\mathrm{PC}$ with a cause of the customer's choosing; (GV-CCC: $p=0.070$ ). Both forms of PC led to similar perceptions of distributive justice (FC-CCC: $p=0.582$ ).

Similarly, with procedural justice, PC with both a fixed cause $\left(M_{\mathrm{FC}}=3.91, S D_{\mathrm{FC}}=1.55\right)$ and with a customer's chosen cause $\left(M_{\mathrm{CCC}}=4.17, S D_{\mathrm{CCC}}=1.37\right)$ led to significantly higher distributive justice than no compensation $\left(M_{\mathrm{NC}}=2.85, S D_{\mathrm{NC}}=1.36\right)$; (FC-NC: $p=0.000$; CCC-NC: $p=0.000)$. Tangible compensation $\left(M_{\mathrm{GV}}=4.75\right.$, $\left.S D_{\mathrm{GV}}=1.41\right)$ led to significantly higher procedural justice than both forms of PC: (GV-FC: $p=0.000$; GV-CCC: $p=0.002)$. The level of perceived procedural justice was similar for both types of PC (FC-CCC: $p=.317$ ). As noted previously, there was a marginally significant interaction effect: $F(3,588)=2.54, p=0.056$. In the private-sector
Table 3 Means ( $S D$ s in parentheses) for the dependent variables by compensation type (Experiment 2B)

\begin{tabular}{lllll}
\hline & $\begin{array}{l}\text { No compensation } \\
(\mathrm{NC})\end{array}$ & $\begin{array}{l}\text { Gift voucher } \\
(\mathrm{GV})\end{array}$ & Fixed cause (FC) & $\begin{array}{l}\text { Customer's chosen } \\
\text { cause (CCC) }\end{array}$ \\
\hline$N$ & 144 & 153 & 151 & 148 \\
Distributive justice & $2.13^{\mathrm{a}}(1.17)$ & $3.88^{\mathrm{b}}(1.57)$ & $3.25^{\mathrm{c}}(1.50)$ & $3.47^{\mathrm{bc}}(1.62)$ \\
$\begin{array}{l}\text { Procedural justice } \\
\text { Post-recovery satisfac- } \\
\text { tion }\end{array}$ & $2.85^{\mathrm{a}}(1.36)$ & $4.75^{\mathrm{b}}(1.41)$ & $3.91^{\mathrm{c}}(1.55)$ & $4.17^{\mathrm{c}}(1.37)$ \\
\hline
\end{tabular}

Means with the same superscript ( $\mathrm{a}$ or $\mathrm{b}$ ) within a row are not significantly different from each other (Bonferroni, $p<0.05$ ) 
setting, the four Compensation conditions all significantly differed from each other ( $p$ 's $<0.001)$. The only instance of a non-significant difference was between the two forms of PC: $p=0.097\left(M_{\mathrm{NC}}=2.75, S D_{\mathrm{NC}}=1.35 ; M_{\mathrm{FC}}=3.65\right.$, $S D_{\mathrm{FC}}=1.64 ; M_{\mathrm{CCC}}=4.03, S D_{\mathrm{CCC}}=1.38 ; M_{\mathrm{GV}}=4.93$, $\left.S D_{\mathrm{GV}}=1.33\right)$. Within the public setting, offering PC with a fixed cause $\left(M_{\mathrm{FC}}=4.17, S D_{\mathrm{FC}}=1.42\right)$ led to higher procedural justice than not offering compensation $\left(M_{\mathrm{NC}}=2.95\right.$, $\left.S D_{\mathrm{NC}}=1.36\right), p=0.000$. However, there was no significant difference in terms of the resulting procedural justice between offering the two forms of PC $\left(M_{\mathrm{CCC}}=4.32\right.$, $\left.S D_{\mathrm{CCC}}=1.35\right), p=0.514$. Further, there was no significant difference between the effects of PC to a customer's chosen cause and a gift voucher $\left(M_{\mathrm{GV}}=4.59, S D_{\mathrm{GV}}=1.47\right)$.

Finally, for post-recovery satisfaction, both forms of PC $\left(M_{\mathrm{FC}}=2.85, S D_{\mathrm{FC}}=1.61 ; M_{\mathrm{CCC}}=3.02, S D_{\mathrm{CCC}}=1.56\right)$ led to significantly higher post-recovery satisfaction than no compensation $\left(M_{\mathrm{NC}}=1.77, S D_{\mathrm{NC}}=1.01\right)$; (FC-NC: $p=0.000$; CCC-NC: $p=0.000)$. Post-recovery satisfaction was significantly higher when tangible compensation $\left(M_{\mathrm{GV}}=3.54\right.$, $S D_{\mathrm{GV}}=1.66$ ) was offered than with either form of PC; (GV-FC: $p=0.001$; GV-CCC: $p=0.016$ ). Finally, both forms of $\mathrm{PC}$ led to similar levels of post-recovery satisfaction; (FC-CCC: $p=1.000$ ).

To summarize, Experiment 2B showed that both types of PC led to higher perceived distributive justice, procedural justice, and post-recovery satisfaction than not offering compensation after a service failure (supporting H3a, H4a, and H5a). Nevertheless, as with Experiment 2A, our results showed that a gift voucher was even more effective in boosting procedural justice and post-recovery satisfaction than either type of PC (H4b and H5b). Although fixed-cause PC was not as effective as tangible compensation, in the form of a gift voucher, in increasing distributive justice, $\mathrm{PC}$ to a cause of the customer's choosing was as effective (H3b). Further, there were no significant differences in the evaluations of the two types of $\mathrm{PC}(\mathrm{H} 3 \mathrm{c}, \mathrm{H} 4 \mathrm{c}$, and $\mathrm{H} 5 \mathrm{c})$. Finally, there were also no main or interaction effects involving the Sector.

\section{General Discussion}

Organizations are continuously seeking new CSR practices that can contribute to their CSR engagement and positively influence the perceptions and behaviors of their customers. The aim of this study was to investigate whether PC could contribute to CSR signaling and justice effects and so contribute to fulfilling corporate ethical and philanthropic responsibilities (the third and fourth dimension of Caroll's pyramid). Our first experiment showed that communicating and explicitly promising PC in the event of a service failure improves CSR image, corporate image, credibility, and WOM-intent among customers. Experiments 2A and 2B further show that offering
PC after a service failure leads to higher levels of distributive justice, procedural justice, and post-recovery satisfaction. Overall, PC leads to improved customer evaluations and, at the same time, contributes to meeting corporate ethical and philanthropic responsibilities. Our study shows that both companies and public organizations can benefit from adding PC to their corporate philanthropy practices.

The conventional corporate practice when using service guarantees is to offer customers some form of tangible compensation after a service failure such as a refund, gift vouchers, or discounts on future purchases. In line with this, the marketing and services management literature on service guarantees has similarly focused on such tangible types of compensation (see Hogreve and Gremler 2009). So why do we suggest companies should switch from these tangible types of compensation to offering prosocial compensation? Our research shows that communicating to potential customers the offering of PC leads to similar positive levels of corporate image, credibility, and WOM-intent as offering a gift voucher. Further, in service recovery situations, $\mathrm{PC}$ has positive effects on perceived justice and post-recovery satisfaction, although admittedly to a lesser extent than a gift voucher. Nevertheless, we argue that PC could have an advantage because it has a strong positive signaling effect on CSR image, which tangible compensation lacks. By enhancing CSR image, we argue that $\mathrm{PC}$ will benefit the organization at large.

This study contributes to the CSR and business ethics literature by introducing a new CSR practice. This practice does not only reflect the responsibility of the organizations in serving society, but also the responsibility of the customers to act in a societal beneficial way (Consumer Social Responsibility-Vitell 2015). It further contributes to signaling theory by showing that, as with other corporate philanthropy practices, $\mathrm{PC}$ has the power to influence potential customers' perceptions of the organization. This study is one of the few to have researched CSR in service operation situations (Bolton and Mattila 2015) and is the first to combine the concepts of CSR and business ethics with service guarantees (for an overview of the service guarantee literature, see Hogreve and Gremler 2009). Service guarantees have the potential to enhance corporate ethical responsibilities by increasing the transparency to customers about what they can expect from the company. Our study also contributes to justice theory by showing that a psychological form of compensation is able to restore perceived justice and boost post-recovery satisfaction. Finally, apart from Thomassen et al. (2017), this research is unique in using signaling theory and justice theory in a public sector setting. It shows that these theories are as applicable in public settings as they are in private settings.

Overall, reflecting on the findings from the three experiments, two aspects turned out differently than we had expected. First, earlier research on customers' evaluations had shown that choice improves value and equity (Mattila 
and Cranage 2005) and has a positive impact on customers' evaluations of an organization as being more ethical, credible, and socially responsible (Howie et al. 2015). Further, research on the effects of cause-related marketing shows that a donation to a cause of the customer's choice leads to improved evaluations compared with a fixed cause determined by the supplier (Grau and Folse 2007; Howie et al. 2015; Robinson et al. 2012). Based on these results, we had expected that prosocial compensation in which the customer was allowed to choose the cause would lead to significantly more positive signaling and justice effects than a fixed cause predetermined by the supplier. However, apart from some minor exceptions, our results did not bear this out. A possible explanation is that being given a choice increases a customer's 'personal costs' in terms of effort and time (Robinson et al. 2012). Customers tend to choose the option with the lowest personal cost in terms of effort and time (Thaler and Sunstein 2008). Therefore choice does not always lead to more positive customer evaluations (e.g., Botti and McGill 2011; Thaler 1980). For example, research on cause-related marketing campaigns (Robinson et al. 2012) found a negative relationship between these personal costs and willingness to participate in an action. In our Experiments 2A and $2 \mathrm{~B}$, the personal costs of fixed-cause $\mathrm{PC}$ was low whereas, when there was a free choice, customers had to think about their favorite cause. This could have influenced the results.

The second somewhat surprising outcome relates to the differences in outcomes between the public and private sectors. Earlier research suggests that the effects of CSR practices on customers' evaluations are moderated by the sector (Pérez and del Bosque 2015; Strahilevitz and Myers 1998). Several factors might influence the signaling effects of PC, possibly leading to different effects in public and private settings. For example, the image of an organization could lead to different PC signaling effects since non-profit organizations are perceived as warmer but less professional than for-profit organizations (Aaker et al. 2010). However, in our findings, there were only minor differences in the signaling and justice effects between our public and private sector settings. One reason for this might be that we, in order to use scenarios that were as similar as possible, used direct exchange situations in all three experiments. That is, in both private and public settings, customers had to pay directly for the product. In such situations, the customers' money can be directly related to the value they receive (Alford 2002). Future research in public settings could investigate the effects of PC in settings where customers do not pay directly for a service. Another reason for the similar results could be that, like corporate services, public services also have to satisfy customers' needs (Vigoda 2002). Further, customers' experiences in corporate settings have been shown to influence their public service expectations (Clarke et al. 2007). The increasing commercialization of public services, and the introduction of many corporate management and customer service innovations, may have shifted customers' expectations of public service delivery to levels similar to those found in the private sector (Clarke et al. 2007; Needham 2006). Taken together, these findings on the public versus private settings suggest it is relevant to study the discrete effects in different situations in future research.

\section{Managerial Recommendations}

CSR-engaged organizations could use PC in the case of service failures instead of offering no compensation or a tangible compensation like money back, a gift voucher or free products/services. In order to work effectively, they should explicitly communicate $\mathrm{PC}$ as an element of a service guarantee. Moreover, it is crucial to actually offer PC in the case a service failure is made. If organizations do not live up to their promise, it will create a backlash and customers will dislike the organization more than when there was no promise made (cf. Thomassen et al. 2017). Finally, in the current study we focused on situations in which there was a low level of service failure severity: customers did not get into big problems due to the service failure. When service failure severity goes up, one might expect that only receiving PC would not be sufficient to compensate for the problems the customers experienced. Future research should study the impact of service failure severity in more detail. The current study, however, indicates that PC can work well for such small service failures. When CSR-engaged organizations use these guidelines, they could use PC as a practice to contribute to their ethical responsibilities by fulfilling customer rights and to their philanthropic responsibilities by donating to charitable causes.

\section{Limitations and Future Research}

We attempted to establish service settings with similar failures and similar service recovery situations in order to compare private and public sectors. Experiments $2 \mathrm{~A}$ and $2 \mathrm{~B}$ showed that failure severity was perceived as similar in both private and public settings. However, the perceived realism of the scenarios in terms of Sector (Experiment 1) and type of Compensation (Experiments 1 and 2B) were not equivalent. The differences in perceived realism could be caused by the fact that compensating for service failures is not yet an everyday practice in public settings. Differences in the perceived realism of the compensation offered could be due to prosocial compensation being a relatively novel practice. This can only be tested when PC becomes a more common form of redress in both private and public organizations. Note, however, that our analysis indicated that realism (or a lack thereof) was not sufficient to explain our findings. That is, compensation and sector had significant effects, with the same pattern of effects, when realism was treated as a covariate. 
We used a vignette approach in order to achieve sufficient sample sizes and gather reliable data to measure the effects on customers' evaluations. Vignette studies have been used in similar service recovery situations (Ohtsubo and Watanabe 2009; Thomassen et al. 2017) and in situations that are emotional for customers (Barkworth and Murphy 2015; Van Doorn et al. 2012). Despite their realism and high internal validity, vignettes remain hypothetical and capture stated rather than revealed preferences. Again, it was impossible to gather data on actual service failures, and the effects that PC has on these, simply because offering PC is not yet a common practice in either companies or public organizations. Nevertheless, we hope this paper will encourage the use of $\mathrm{PC}$ and that, in the near future, it will be possible to research the emotional and cognitive effects of $\mathrm{PC}$ on genuine customers after service failures.

We view this research on the effects of PC as the starting point for more research on PC. In addition to the above avenue for future research, we have identified five other relevant avenues that could enhance understanding of customer's attitudes towards PC and generate insights into how to design effective PC practices. The second avenue relates to possible moderating effects on PC outcomes of the types and personality traits of customers. Several studies (e.g., Bolton and Mattila 2015; Robinson et al. 2012) have shown that these significantly affect the outcomes of CSR practices. For example, the effects of choice in cause-related marketing campaigns depend on the collectivism (high versus low) of customers (Robinson et al. 2012).

A third avenue could usefully address the effects of different types of PC. In our research, we investigated the effects of PC with either a fixed predetermined cause or where the customer has a completely free choice of recipient. The effects of offering choice within a predetermined list of causes, which would reduce a customer's personal costs, could be investigated. In addition, the effects of customers being able to choose between prosocial and tangible compensation, situations in which the company matches a customer's own donations (Karlan and List 2007; Karlan et al. 2011), and situations in which customers can choose between PC in the form of a donation or of employee volunteering (Plewa et al. 2015) could be studied. In a similar vein, the effects of different levels of PC could be studied. While we offered token amounts for the time and money customers had lost due to service failure, the service recovery literature (Gelbrich et al. 2015; McQuilken et al. 2013) and the CSR literature (Folse et al. 2010) show that different compensation and donation amounts can have different effects on customers' evaluations. In other words, studying both the type of PC and the amount of PC could foster a better understanding of the scope of the PC effect.

A fourth avenue could address the effects that cause fit and a customer's perception of the corporate motivation in offering PC have. Cause fit refers to the match between "the company, its products, branding, positioning, and target audience, on one hand, and the needs of its CSR initiatives and groups involved in them, on the other hand" (Pérez and del Bosque 2013b, p. 158). As with cause-related marketing campaigns, the effectiveness of offering PC could depend on how the customer perceives the fit between the charitable cause and the company (Robinson et al. 2012). The effects of CSR practices, such as PC, in part depend on how such altruistic corporate actions are perceived by customers (Brown and Dacin 1997; Howie et al. 2015). As with other types of corporate philanthropy (Kang and Hustvedt 2014; Liket and Simaens 2015), the perceived motives for donating to charitable causes could change the effects that PC has. A poor fit and a negatively perceived corporate motivation, such as to gain tax advantages, could lead to skepticism among customers (Folse et al. 2010). These aspects were not addressed in our experiments, and follow-up research could investigate their influence on customers' evaluations.

The next avenue concerns the effects of employee behavior when offering PC to customers in service recovery situations. In line with Crisafully and Singh (2016), we kept the interaction with the employee (interactional justice) intentionally constant in Experiments 2A and 2B in order to focus on the effects of compensation and the payout process. However, in daily practice, there will be differences in employee behavior in service recovery situations and this could influence the levels of perceived justice (e.g., Homburg and Fürst 2005) and of customer satisfaction. Björlin Lidén and Skålén (2003, p. 52) described a hotel setting where employees focused on offering tangible compensation, rather than displaying empathic and responsive behavior, to guests after a service failure. This resulted in decreased levels of guest satisfaction. Research in PC settings could similarly investigate the effects on customers' evaluations of differences in employee behavior when resolving problems and offering PC. Moreover, studying the role of employees in PC could further our understanding of CSR as it would take a broader perspective than the traditional focus on customers as key drivers of CSR initiatives (cf. Wang et al. 2016).

Finally, future research could focus on organizational enablers, i.e., the boundary conditions for strategically implementing service guarantees and $\mathrm{PC}$ in an organization, and making this part of everyday practice. For example, companies with better outside-in corporate abilities may find it easier to implement and use the concept than internally oriented companies without a customer focus. Follow-up research could determine the enablers, their importance, and possible clustering in order to support the implementation of PC (see also Thomassen et al. 2014).

\section{Conclusions}

Organizations could use PC in order to contribute to their ethical and philanthropic CSR responsibilities. Prosocial compensation offers value and equity to customers 
experiencing a service failure by offering them psychological compensation and, at the same time, enhances the organization's CSR image. By showing the benefits of the corporate philanthropic practice of offering PC, we have broadened the range of options that companies and public organizations can use to satisfy customers and fulfill their CSR obligations.

Acknowledgements We would like to thank the editor and three anonymous $J B E$ reviewers for the many valuable and helpful comments. We also would like to thank Boudewijn de Bruin for insightful remarks on earlier versions of this work.

Funding This research was supported by a VENI Grant (\#451-13-031) awarded to the second author by The Netherlands Organization for Scientific Research (NWO). The authors received no other third-party financial support for the research, authorship, and/or publication of this article.

\section{Compliance with Ethical Standards}

Conflict of interest The authors declare that they have no conflict of interest.
Ethical Standards All three experiments have been approved by the ethical committee of the university involved and comply with the required ethical standards. All participants of the three experiments have given their informed consent prior to participation.

Open Access This article is distributed under the terms of the Creative Commons Attribution 4.0 International License (http://creativeco mmons.org/licenses/by/4.0/), which permits unrestricted use, distribution, and reproduction in any medium, provided you give appropriate credit to the original author(s) and the source, provide a link to the Creative Commons license, and indicate if changes were made.

\section{Appendix}

See Tables 4, 5, and 6 .

Table 4 Scales and items used in the three experiments

\begin{tabular}{|c|c|c|}
\hline Dependent variable & Used in exp'mt & Items \\
\hline CSR image & 1 & $\begin{array}{l}\text { (a) This internet store/governmental visa organization is a socially responsible organization } \\
\text { (b) This internet store/governmental visa organization is concerned about the wellbeing of society } \\
\text { (c) I think this internet store/governmental visa organization has legitimate interest in improving society } \\
\text { (d) Contributing to society appears important to this internet store/governmental visa organization } \\
\text { ( } 1=\text { strongly disagree, } 7=\text { strongly agree) The scales are presented separately for each sector }\end{array}$ \\
\hline Corporate image & 1 & $\begin{array}{l}\text { (a) Negative-positive } \\
\text { (b) Unfavorable-favorable } \\
\text { (c) Bad-Good } \\
\text { (d) Dislike-Like ( } 7 \text { point scale) }\end{array}$ \\
\hline Credibility & 1 & $\begin{array}{l}\text { (a) I have sincere doubts about the ability of the internet store/governmental visa organization to keep its } \\
\text { promises (R) } \\
\text { (b) There would be no risk in dealing with this internet store/governmental visa organization } \\
\text { (c) I would feel very confident in dealing with this internet store/governmental visa organization } \\
\text { (d) I am confident in the ability of this internet store/governmental visa organization to perform as prom- } \\
\text { ised ( } 1=\text { strongly disagree, } 7=\text { strongly agree). The scales are presented separately for each sector }\end{array}$ \\
\hline WOM-intent & 1 & $\begin{array}{l}\text { (a) I would say positive things about this internet store/governmental visa organization to other people } \\
\text { (b) If someone talks negatively about this internet store/governmental visa organization I would argue } \\
\text { against them ( } 1=\text { most unlikely, } 7=\text { most likely). The scales are presented separately for each sector }\end{array}$ \\
\hline Severity of service failure & $2 \mathrm{~A} \& 2 \mathrm{~B}$ & (a) How would you rate the importance of the service failure? ( $1=$ unimportant, $7=$ extremely important $)$ \\
\hline Distributive justice & $2 \mathrm{~A} \& 2 \mathrm{~B}$ & $\begin{array}{l}\text { (a) The compensation for the inconvenience is fair } \\
\text { (b) I did not receive what I deserve }(\mathrm{R}) \\
\text { (c) The outcome I received was not fair }(\mathrm{R})(1=\text { strongly disagree, } 7=\text { strongly agree })\end{array}$ \\
\hline Procedural justice & $2 \mathrm{~A} \& 2 \mathrm{~B}$ & $\begin{array}{l}\text { (a) The organization used a good procedure to solve my problem } \\
\text { (b) If I was an employee of that organization, I would have acted similarly } \\
\text { (c) I felt taken seriously ( } 1=\text { strongly disagree, } 7=\text { strongly agree })\end{array}$ \\
\hline Post-recovery satisfaction & $2 \mathrm{~A} \& 2 \mathrm{~B}$ & $\begin{array}{l}\text { (a) Overall, how satisfied or dissatisfied did this experience make you feel? }(1=\text { very dissatisfied, } 7=\text { very } \\
\text { satisfied) } \\
\text { (b) How well did this service experience meet your needs? }(1=\text { not at all, } 7=\text { absolutely yes }) \\
\text { (c) Overall, I am very satisfied with this experience }(1=\text { strongly disagree, } 7=\text { strongly agree })\end{array}$ \\
\hline Realism of the scenario & $1,2 \mathrm{~A} \& 2 \mathrm{~B}$ & (a) To what extent do you think this was a realistic situation? $(1=$ not at all realistic, $7=$ very realistic) \\
\hline
\end{tabular}


Table 5 Main and interaction effects of three experiments

\begin{tabular}{|c|c|c|}
\hline \multicolumn{3}{|c|}{ Experiment 1: signaling effects-US citizens } \\
\hline \multicolumn{2}{|l|}{ Dependent variable } & Main/interaction effect \\
\hline \multicolumn{3}{|l|}{ CSR image } \\
\hline \multicolumn{2}{|l|}{ Compensation } & $F(3,595)=15.13, p=0.000$ \\
\hline \multicolumn{2}{|l|}{ Sector } & $F(1,595)=6.21, p=0.013$ \\
\hline \multicolumn{2}{|l|}{ Compensation $\times$ sector } & $F(3,595)=0.84, p=0.474$ \\
\hline \multicolumn{3}{|l|}{ Corporate image } \\
\hline \multicolumn{2}{|l|}{ Compensation } & $F(3,595)=4.78, p=0.003$ \\
\hline \multicolumn{2}{|l|}{ Sector } & $F(1,595)=0.83, p=0.363$ \\
\hline \multicolumn{2}{|l|}{ Compensation $\times$ sector } & $F(3,595)=0.82, p=0.484$ \\
\hline \multicolumn{3}{|l|}{ Credibility } \\
\hline \multicolumn{2}{|l|}{ Compensation } & $F(3,595)=6.28, p=0.000$ \\
\hline \multicolumn{2}{|l|}{ Sector } & $F(1,595)=0.04, p=0.843$ \\
\hline \multicolumn{2}{|l|}{ Compensation $\times$ sector } & $F(3,595)=1.86, p=0.136$ \\
\hline \multicolumn{3}{|l|}{ WOM-intent } \\
\hline \multicolumn{2}{|l|}{ Compensation } & $F(3,595)=7.06, p=0.000$ \\
\hline \multicolumn{2}{|l|}{ Sector } & $F(1,595)=2.80, p=0.095$ \\
\hline \multicolumn{2}{|l|}{ Compensation $\times$ sector } & $F(3,595)=0.03, p=0.991$ \\
\hline \multicolumn{3}{|c|}{ Justice effects: experiment 2A—Dutch students \& Experiment 2B-mainly US citizens } \\
\hline \multirow[t]{2}{*}{ Dependent variable } & \multicolumn{2}{|l|}{ Main/interaction effect } \\
\hline & Experiment $2 \mathrm{~A}$ & Experiment $2 \mathrm{~B}$ \\
\hline \multicolumn{3}{|l|}{ Distributive justice } \\
\hline$F(2,142)=13.10, p=0.000$ & $F(2,142)=13.10, p=0.000$ & $F(3,588)=38.02, p=0.000$ \\
\hline Sector & $F(1,142)=2.57, p=0.111$ & $F(1,588)=3.79, p=0.187$ \\
\hline Compensation $\times$ sector & $F(2,142)=0.82, p=0.445$ & $F(3,588)=1.53, p=0.205$ \\
\hline \multicolumn{3}{|l|}{ Procedural justice } \\
\hline Compensation & $F(2,142)=9.41, p=0.000$ & $F(3,588)=46.62, p=0.000$ \\
\hline Sector & $F(1,142)=1.48, p=0.226$ & $F(1,588)=2.06, p=0.152$ \\
\hline Compensation $\times$ sector & $F(2,142)=0.85, p=0.431$ & $F(3,588)=2.54, p=0.056$ \\
\hline \multicolumn{3}{|l|}{ Post-recovery satisfaction } \\
\hline Compensation & $F(2,142)=3.09, p=0.049$ & $F(3,588)=36.71, p=0.000$ \\
\hline Sector & $F(1,142)=0.29, p=0.591$ & $F(1,588)=1.24, p=0.266$ \\
\hline Compensation $\times$ sector & $F(2,142)=0.86, p=0.425$ & $F(3,588)=0.73, p=0.534$ \\
\hline
\end{tabular}

Values in bold are significant $(p<0.05)$ 
Table 6 Summary of means and standard deviations for the dependent variables

\begin{tabular}{|c|c|c|c|c|c|c|c|}
\hline \multicolumn{8}{|c|}{ Experiment 1: signaling effects-US citizens } \\
\hline \multirow{3}{*}{$\begin{array}{l}\text { Dependent } \\
\text { variable }\end{array}$} & \multirow[t]{3}{*}{ Compensation } & \multicolumn{6}{|c|}{ Customers' evaluations } \\
\hline & & \multicolumn{2}{|c|}{ Total $(N=603)$} & \multicolumn{2}{|c|}{ Internet store $(N=293)$} & \multicolumn{2}{|c|}{ Travel visa $(N=310)$} \\
\hline & & M & SD & M & SD & M & SD \\
\hline \multirow{4}{*}{$\begin{array}{l}\text { CSR } \\
\text { image }\end{array}$} & No compensation (NC) & 4.62 & 1.14 & 4.41 & 1.14 & 4.86 & 1.11 \\
\hline & Gift voucher (GV) & 4.95 & 1.13 & 4.82 & 1.03 & 5.05 & 1.20 \\
\hline & Fixed cause $(\mathrm{FC})$ & 5.37 & 1.11 & 5.25 & 1.15 & 5.47 & 1.08 \\
\hline & $\begin{array}{l}\text { Customer's chosen cause } \\
\text { (CCC) }\end{array}$ & 5.40 & 1.20 & 5.38 & 1.10 & 5.41 & 1.30 \\
\hline \multirow{4}{*}{$\begin{array}{l}\text { Corporate } \\
\text { image }\end{array}$} & No compensation (NC) & 5.41 & 1.06 & 5.28 & 0.96 & 5.56 & 1.15 \\
\hline & Gift voucher (GV) & 5.76 & 0.90 & 5.82 & 0.80 & 5.72 & 0.97 \\
\hline & Fixed cause (FC) & 5.73 & 1.09 & 5.71 & 1.24 & 5.75 & 0.96 \\
\hline & $\begin{array}{l}\text { Customer's chosen cause } \\
\text { (CCC) }\end{array}$ & 5.86 & 1.14 & 5.81 & 1.03 & 5.91 & 1.26 \\
\hline \multirow[t]{4}{*}{ Credibility } & No compensation (NC) & 4.52 & 0.95 & 4.42 & 0.81 & 4.63 & 1.09 \\
\hline & Gift voucher $(\mathrm{GV})$ & 4.93 & 0.99 & 5.09 & 0.83 & 4.80 & 1.09 \\
\hline & Fixed cause (FC) & 4.99 & 1.11 & 4.91 & 1.15 & 5.06 & 1.09 \\
\hline & $\begin{array}{l}\text { Customer's chosen cause } \\
\text { (CCC) }\end{array}$ & 4.96 & 1.18 & 5.02 & 1.12 & 4.89 & 1.26 \\
\hline \multirow{4}{*}{$\begin{array}{l}\text { WOM- } \\
\text { intent }\end{array}$} & No compensation (NC) & 4.09 & 1.26 & 3.99 & 1.16 & 4.21 & 1.36 \\
\hline & Gift voucher (GV) & 4.67 & 1.24 & 4.56 & 1.18 & 4.75 & 1.28 \\
\hline & Fixed cause (FC) & 4.67 & 1.35 & 4.61 & 1.37 & 4.73 & 1.33 \\
\hline & $\begin{array}{l}\text { Customer's chosen cause } \\
\text { (CCC) }\end{array}$ & 4.71 & 1.41 & 4.61 & 1.41 & 4.81 & 1.42 \\
\hline \multicolumn{8}{|c|}{ Experiment 2A: justice effects—Dutch students } \\
\hline \multirow{3}{*}{$\begin{array}{l}\text { Dependent } \\
\text { variable }\end{array}$} & \multirow[t]{3}{*}{ Compensation } & \multicolumn{6}{|c|}{ Customers' evaluations } \\
\hline & & \multicolumn{2}{|c|}{ Total $(N=148)$} & \multicolumn{2}{|c|}{ Internet store $(N=76)$} & \multicolumn{2}{|c|}{ Municipality $(N=72)$} \\
\hline & & M & SD & M & SD & M & SD \\
\hline \multirow{3}{*}{$\begin{array}{l}\text { Dis- } \\
\text { tributive } \\
\text { justice }\end{array}$} & Gift voucher $(\mathrm{GV})$ & 4.31 & 1.28 & 4.63 & 1.27 & 4.16 & 1.28 \\
\hline & Fixed cause (FC) & 3.08 & 1.32 & 3.07 & 1.21 & 3.10 & 1.45 \\
\hline & $\begin{array}{l}\text { Customer's chosen cause } \\
\text { (CCC) }\end{array}$ & 3.40 & 1.28 & 3.61 & 1.07 & 2.99 & 1.58 \\
\hline \multirow{3}{*}{$\begin{array}{l}\text { Procedural } \\
\text { justice }\end{array}$} & Gift voucher $(\mathrm{GV})$ & 5.14 & 1.44 & 5.54 & 1.20 & 4.94 & 1.53 \\
\hline & Fixed cause (FC) & 3.91 & 1.42 & 3.84 & 1.23 & 3.99 & 1.63 \\
\hline & $\begin{array}{l}\text { Customer's chosen cause } \\
\text { (CCC) }\end{array}$ & 4.43 & 1.54 & 4.58 & 1.36 & 4.12 & 1.86 \\
\hline \multirow{3}{*}{$\begin{array}{l}\text { Post- } \\
\text { recovery } \\
\text { satisfac- } \\
\text { tion }\end{array}$} & Gift voucher (GV) & 3.25 & 1.39 & 3.38 & 1.45 & 3.19 & 1.37 \\
\hline & Fixed cause (FC) & 2.60 & 1.18 & 2.48 & 0.86 & 2.74 & 1.46 \\
\hline & $\begin{array}{l}\text { Customer's chosen cause } \\
\text { (CCC) }\end{array}$ & 2.96 & 1.28 & 3.10 & 1.19 & 2.67 & 1.44 \\
\hline
\end{tabular}


Table 6 (continued)

Experiment 2B: justice effects—mainly US citizens

\begin{tabular}{|c|c|c|c|c|c|c|c|}
\hline \multirow{3}{*}{$\begin{array}{l}\text { Dependent vari- } \\
\text { able }\end{array}$} & \multirow[t]{3}{*}{ Compensation } & \multicolumn{6}{|c|}{ Customers' evaluations } \\
\hline & & \multicolumn{2}{|c|}{ Total $(N=596)$} & \multicolumn{2}{|c|}{ Internet store $(N=298)$} & \multicolumn{2}{|c|}{ Travel visa $(N=298)$} \\
\hline & & M & SD & M & SD & M & $\mathrm{SD}$ \\
\hline \multirow{4}{*}{$\begin{array}{l}\text { Distributive } \\
\text { justice }\end{array}$} & No compensation (NC) & 2.13 & 1.17 & 2.05 & 1.22 & 2.21 & 1.21 \\
\hline & Gift voucher (GV) & 3.88 & 1.57 & 4.01 & 1.48 & 3.77 & 1.64 \\
\hline & Fixed cause (FC) & 3.25 & 1.50 & 3.01 & 1.54 & 3.47 & 1.44 \\
\hline & $\begin{array}{l}\text { Customer's chosen } \\
\text { cause (CCC) }\end{array}$ & 3.47 & 1.62 & 3.35 & 1.59 & 3.61 & 1.65 \\
\hline \multirow[t]{4}{*}{ Procedural justice } & No compensation (NC) & 2.85 & 1.36 & 2.75 & 1.35 & 2.95 & 1.36 \\
\hline & Gift voucher $(\mathrm{GV})$ & 4.75 & 1.41 & 4.93 & 1.33 & 4.59 & 1.47 \\
\hline & Fixed cause (FC) & 3.91 & 1.55 & 3.65 & 1.64 & 4.17 & 1.42 \\
\hline & $\begin{array}{l}\text { Customer's chosen } \\
\text { cause (CCC) }\end{array}$ & 4.17 & 1.37 & 4.03 & 1.38 & 4.32 & 1.35 \\
\hline \multirow{4}{*}{$\begin{array}{l}\text { Post-recovery } \\
\text { satisfaction }\end{array}$} & No compensation (NC) & 1.77 & 1.01 & 1.74 & 1.05 & 1.81 & 0.98 \\
\hline & Gift voucher (GV) & 3.54 & 1.66 & 3.61 & 1.63 & 3.49 & 1.70 \\
\hline & Fixed cause (FC) & 2.85 & 1.61 & 2.67 & 1.70 & 3.03 & 1.51 \\
\hline & $\begin{array}{l}\text { Customer's chosen } \\
\text { cause (CCC) }\end{array}$ & 3.02 & 1.56 & 2.91 & 1.54 & 3.14 & 1.59 \\
\hline
\end{tabular}

\section{References}

Aaker, D. A. (1996). Building strong brands. New York: The Free Press.

Aaker, J., Vohs, K. D., \& Mogilner, C. (2010). Nonprofits are seen as warm and for-profits as competent: Firm stereotypes matter. Journal of Customer Research, 37(2), 224-237.

Adams, J. S. (1965). Inequity in social exchange. In L. Berkowitz (Ed.), Advances in experimental social psychology. New York: Academic Press.

Aggarwal, P. (2004). The effects of brand relationship norms on customer attitudes and behavior. Journal of Customer Research, 31(June), 87-101.

Aguinis, H., \& Glavas, A. (2012). What we know and don't know about corporate social responsibility: A review and research agenda. Journal of Management, 38(4), 932-968.

Ahaus, C. T. B., \& De Haan, E. (2010). Integrated complaint management: Source of inspiration for customer loyalty, brand image and quality improvement (Dutch language). Deventer: Kluwer.

Aknin, L. B., Dunn, E. W., Whillans, A. V., Grant, A. M., \& Norton, M. I. (2013). Making a difference matters: Impact unlocks the emotional benefits of prosocial spending. Journal of Economic Behavior \& Organization, 88(April), 90-95.

Alexander, E. C. (2002). Consumer reactions to unethical service recovery. Journal of Business Ethics, 36(3), 223-237.

Alford, J. (2002). Defining the client in the public sector: A socialexchange perspective. Public Administration Review, 62(3), 337-346.

Anderson, E. (1998). Customer satisfaction and word of mouth. Journal of Service Research, 1(1), 5-17.

Anderson, E. W., Fornell, C., \& Mazvancheryl, S. K. (2004). Customer satisfaction and shareholder value. Journal of Marketing, 68(October), 172-185.

Andreoni, J. (2006). Philanthropy. In S.-C. Kolm, L.-A. Gérard-Varet \& J. Mercier-Ythier (Eds.), Handbook on the economics of giving, reciprocity and altruism (Vol. 2). Amsterdam: Elsevier.
Barkworth, J. M., \& Murphy, K. (2015). Procedural justice policing and citizen compliance behaviour: The importance of emotion. Psychology, Crime \& Law, 21(3), 254-273.

Bekkers, R., \& Wiepking, P. (2011). A literature review of empirical studies of philanthropy: Eight mechanisms that drive charitable giving. Nonprofit and Voluntary Sector Quarterly, 40(5), 924-973.

Björlin Lidén, S., \& Edvardsson, B. (2003). Customer expectations on service guarantees. Managing Service Quality, 13(5), 338-348.

Björlin Lidén, S., \& Skålén, P. (2003). The effect of service guarantees on service recovery. International Journal of Service Industry Management, 14(1), 36-58.

Bolton, L. E., \& Mattila, A. S. (2015). How does corporate social responsibility affect customer response to service failure in buyer-seller relationships? Journal of Retailing, 91(1), 140-153.

Botti, S., \& McGill, A. L. (2011). The locus of choice: Personal causality and satisfaction with hedonic and utilitarian decisions. Journal of Consumer Research, 37(2), 1065-1078.

Brown, T. J., \& Dacin, P. A. (1997). The company and the product: Corporate associations and customer product responses. The Journal of Marketing, 61(1), 68-84.

Campbell, J. L. (2007). Why would corporations behave in socially responsible ways? An institutional theory of corporate social responsibility. Academy of Management Review, 32(3), 946-967.

Cantrell, J. E., Kyriazis, E., \& Noble, G. (2015). Developing CSR giving as a dynamic capability for salient stakeholder management. Journal of Business Ethics, 130(2), 403-421.

Carroll, A. B. (1991). The pyramid of corporate social responsibility: Toward the moral management of organizational stakeholders. Business Horizons, 34(4), 39-48.

Carroll, A. B., \& Shabana, K. M. (2010). The business case for corporate social responsibility: A review of concepts, research and practice. International Journal of Management Reviews, 12(1), $85-105$.

Casado-Díaz, A. B., \& Nicolau-Gonzálbez, J. L. (2009). Explaining customer complaining behaviour in double deviation scenarios: 
The banking services. The Service Industries Journal, 29(12), $1659-1668$

Chernev, A., \& Blair, S. (2015). Doing well by doing good: The benevolent halo of corporate social responsibility. Journal of Consumer Research, 41(6), 1412-1425.

Clarke, J., Newman, J., Smith, N., Vidler, E., \& Westmarland, L. (2007). Creating citizen-customers: Changing publics and changing public services. London: Sage Publications.

Colwell, S. R., Zyphur, M. J., \& Schminke, M. (2011). When does ethical code enforcement matter in the inter-organizational context? The moderating role of switching costs. Journal of Business Ethics, 104(1), 47-58.

Connelly, B. L., Certo, S. T., Ireland, R. D., \& Retzel, C. R. (2011). Signaling theory: A review and assessment. Journal of Management, 37(1), 39-67.

Consumers International (2009). How are consumer rights defined? World consumer day: History and purpose. http://www.consu mersinternational.org.

Crisafulli, B., \& Singh, J. (2016). Service guarantee as a recovery strategy. The impact of guarantee terms on perceived justice and firm motives. Journal of Service Management, 27(2), 117-143.

Del Río-Lanza, A. B., Vázques-Cassieles, R., \& Díaz-Martín, A. M. (2009). Satisfaction with service recovery: Perceived justice and emotional responses. Journal of Business Research, 62(8), 775-781.

Dunn, E. W., Aknin, L. B., \& Norton, M. I. (2008). Spending money on others promotes happiness. Science, 319(March 21), 1687-1688.

Erevelles, S., Roy, A., \& Yip, L. S. C. (2001). The universality of the signal theory for products and services. Journal of Business Research, 52(2), 175-187.

Field, A. (2013). Discovering statistics using IBM SPSS statistics (4th edn.). London: Sage.

Folse, J. A. G., Niedrich, R. W., \& Grau, S. L. (2010). Cause-related marketing: The effects of purchase quantity and firm donation amount on customer inferences and participation intentions. Journal of Retailing, 86(4), 295-309.

Gautier, A., \& Pache, A.-C. (2015). Research on corporate philanthropy: A review and assessment. Journal of Business Ethics, 126(3), 343-369.

Gelbrich, K., Gäthke, J., \& Grégoire, Y. (2015). How much compensation should a firm offer for a flawed service? An examination of the nonlinear effects of compensation on satisfaction. Journal of Service Research, 18(1), 107-123.

Gerber, A. S., \& Green, D. P. (2012). Field experiments: design, analysis, and interpretation. New York: W.W. Norton.

Grau, S. L., \& Folse, J. A. G. (2007). Cause-related marketing (CRM): The influence of donation proximity and message-framing cues on the less-involved customer. Journal of Advertising, 36(4), $19-33$.

Grohmann, B., \& Bodur, H. O. (2015). Brand social responsibility: Conceptualization, measurement, and outcomes. Journal of Business Ethics, 131(2), 375-399.

Groza, M. D., Pronschinske, M. R., \& Walker, M. (2011). Perceived organizational motives and customer responses to proactive and reactive CSR. Journal of Business Ethics, 102(4), 639-652.

Hayes, A. F. (2009). Introduction to mediation, moderation, and conditional process analysis: A regression-based approach. New York: Guildford Press.

Hocutt, M. A., \& Bowers, M. R. (2005). The impact of service guarantees on customer responses in the hotel industry. Journal of Hospitality \& Leisure Marketing, 13(1), 5-23.

Hogreve, J., \& Gremler, D. D. (2009). Twenty years of service guarantee research: A synthesis. Journal of Service Research, 11(4), 322-343.
Homburg, C., \& Fürst, A. (2005). How organizational complaint handling drives customer loyalty: An analysis of the mechanistic and the organic approach. Journal of Marketing, 69(3), 95-114.

Howie, K. M., Yang, L., Vitell, S. J., Bush, V., \& Vorhies, D. (2015). Customer participation in cause-related marketing: An examination of effort demands and defensive denial. Journal of Business Ethics. https://doi.org/10.1007/s10551-015-2961-1.

Huang, W.-H., \& Lin, T. D. (2011). Developing effective service compensation strategies: Is a price reduction more effective than a free gift? Journal of Service Management, 22(2), 202-216.

Hur, W.-M., Kim, H., \& Woo, J. (2014). How CSR leads to corporate brand equity: Mediating mechanisms of corporate brand credibility and reputation. Journal of Business Ethics, 125(1), 75-86.

Ingram, R., Skinner, S. J., \& Taylor, V. A. (2005). Consumers' evaluation of unethical marketing behaviors: The role of customer commitment. Journal of Business Ethics, 62(3), 237-252.

Kang, J., \& Hustvedt, G. (2014). Building trust between consumers and corporations: The role of consumer perceptions of transparency and social responsibility. Journal of Business Ethics, 125(2), 253-265.

Karlan, D., \& List, J. A. (2007). Does price matter in charitable giving? Evidence from a large-scale natural field experiment. American Economic Review, 97(5), 1774-1793.

Karlan, D., List, J. A., \& Shafir, E. (2011). Small matches and charitable giving: Evidence from a natural field experiment. Journal of Public Economics, 95(5), 344-350.

Kiessling, T., Isaksson, L., \& Yasar, B. (2016). Market orientation and CSR: Performance implications. Journal of Business Ethics, 137(2), 269-284.

Kim, K., \& Choi, S. (2007). Understanding the impacts of sponsorship. Induced beliefs on corporate credibility and attitude toward the sponsor. American Academy of Advertising Conference, Burington, VT.

Kim, N., \& Ulgado, F. M. (2012). The effect of on-the-spot versus delayed compensation: The moderating role of failure severity. Journal of Services Marketing, 26(3), 158-167.

Larsen, G. (1998). Rural New Zealand: An appraisal of consumer policy requirements. Unpublished MCom Dissertation. University of Otago, Dunedin.

Larsen, G., \& Lawson, R. (2013). Consumer rights: An assessment of justice. Journal of Business Ethics, 112(3), 515-528.

Lev, B., Petrovits, C., \& Radhakrishnan, S. (2010). Is doing good good for you? How corporate charitable contributions enhance revenue growth. Strategic Management Journal, 31(2), 182-200.

Lii, Y.-S., \& Lee, M. (2012). The joint effects of compensation frames and price levels on service recovery of online pricing error. Managing Service Quality, 22(1), 4-20.

Liket, K., \& Simaens, A. (2015). Battling the devolution in the research on corporate philanthropy. Journal of Business Ethics, 126(2), 285-308.

Luo, X. (2005). A contingent perspective on the advantages of stores' strategic philanthropy for influencing consumer behaviour. Journal of Consumer Behaviour, 4(5), 390-401.

Luo, X., \& Bhattacharya, C. B. (2006). Corporate social responsibility, customer satisfaction, and market value. Journal of Marketing, 70(4), 1-18.

Lusch, R. F., \& Vargo, S. L. (2014). The service-dominant logic of marketing: Dialog, debate, and directions. Cambridge: Cambridge University Press.

Madden, K., Scaife, W., \& Crissman, K. (2006). How and why small to medium size enterprises (SMEs) engage with their communities: An Australian study. International Journal of Nonprofit and Voluntary Sector Marketing, 11(1), 49-60.

Magnini, V. P., Ford, J. B., Markowski, E. P., \& Honeycutt, E. D. (2007). The service recovery paradox: Justifiable theory or smoldering myth? Journal of Services Marketing, 21(3), 213-225. 
Marmorstein, H., Sarel, D., \& Lassar, W. M. (2001). Increasing the persuasiveness of a service guarantee: The role of service process evidence. Journal of Services Marketing, 15, 147-159.

Mattila, A. S. (2001). The effectiveness of service recovery in a multi industry setting. Journal of Services Marketing, 15(7), 583-596.

Mattila, A. S., \& Cranage, D. (2005). The impact of choice on fairness in the context of service recovery. Journal of Services Marketing, 19(5), 271-279.

McCollough, M. A., Berry, L. L., \& Yadav, M. S. (2000). An empirical investigation of customer satisfaction after service failure and recovery. Journal of Service Research, 3(2), 121-137.

McDougall, G. H. G., Levesque, T., \& VanderPlaat, P. (1998). Designing the service guarantee: Unconditional or specific? The Journal of Services Marketing, 12(4), 278-293.

McQuilken, L., McDonald, H., \& Vocino, A. (2013). Is guarantee compensation enough? The important role of fix and employee effort in restoring justice. International Journal of Hospitality Management, 33(June), 41-50.

Milakovich, M. E. (2003). Balancing customer service, empowerment and performance with citizenship, responsiveness and political accountability. International Public Management Review, 4(1), 61-82.

Needham, C. E. (2006). Customer care and the public service ethos. Public Administration, 84(4), 845-860.

Ohtsubo, Y., \& Watanabe, E. (2009). Do sincere apologies need to be costly? Test of a costly signalling model of apology. Evolution and Human Behavior, 30(2), 114-123.

Oliver, R. L. (1993). Cognitive, affective, and attribute bases of the satisfaction response. Journal of Customer Research, 20(3), 418-430.

Oppenheimer, D. M., Meyvis, T., \& Davidenko, N. (2009). Instructional manipulation checks: Detecting satisficing to increase statistical power. Journal of Experimental Social Psychology, 45(4), 867-872.

Ostrom, A. L., \& Iacobucci, D. (1998). The effect of guarantees on customers' evaluation of services. The Journal of Services Marketing, 12(5), 362-378.

Pérez, A., \& del Bosque, I. R. (2013a). Measuring CSR image: Three studies to develop and to validate a reliable measurement tool. Journal of Business Ethics, 118(2), 265-286.

Pérez, A., \& del Bosque, I. R. (2013b). Extending on the formation process of CSR image. Social Marketing Quarterly, 19(3), 156-171.

Pérez, A., \& del Bosque, I. R. (2015). An integrative framework to understand how CSR affects customer loyalty through identification, emotions and satisfaction. Journal of Business Ethics, 129(3), 571-584.

Pérez, A., García de los Salmones, M. M., \& del Bosque, I. R. (2013). The effect of corporate associations on consumer behaviour. European Journal of Marketing, 47(1/2), 218-238.

Pfau, M., Haigh, M. M., Sims, J., \& Wigley, S. (2008). The influence of corporate social responsibility campaigns on public opinion. Corporate Reputation Review, 11(2), 145-154.

Pigors, M., \& Rockenbach, B. (2016). Consumer Social Responsibility. Management Science, 62, 3123-3137.

Plewa, C., Conduit, J., Quester, P. G., \& Johnson, C. (2015). The impact of corporate volunteering on CSR image: A customer perspective. Journal of Business Research, 127(3), 643-659.

Robinson, S. R., Imak, C., \& Jayachandran, S. (2012). Choice of cause in cause-related marketing. Journal of Marketing, 76(4), 126-139.

Roggeveen, A. L., Goodstein, R. C., \& Grewal, D. (2014). Improving the effects of guarantees: The role of a retailer's reputation. Journal of Retailing, 90(1), 27-39.

Roschk, H., \& Gelbrich, K. (2014). Identifying appropriate compensation types of service failures: A meta-analytic and experimental analysis. Journal of Service Research, 17(2), 195-211.
Schoefer, K., \& Ennew, C. (2005). The impact of perceived justice on customers' emotional responses to service complaint experiences. Journal of Services Marketing, 19(5), 261-270.

Siu, N. Y.-M., Zhang, T. J.-F., \& Yau, C.-Y. J. (2013). The roles of justice and customer satisfaction in customer retention: A lesson from service recovery. Journal of Business Ethics, 114(4), 675-686.

Smith, S. M., \& Alcorn, D. S. (1991). Cause marketing: A new direction in the marketing of corporate responsibility. Journal of Consumer Marketing, 8(3), 19-34.

Spence, M. (1974). Market-signaling. Cambridge: Harvard University Press.

Strahilevitz, M., \& Myers, J. G. (1998). Donations to cause as purchase incentives: How well they work may depend on what you are trying to sell. Journal of Customer Research, 24(2), 434-446.

Tabachnick, B. G., \& Fidell, L. S. (2001). Using multivariate statistics (4th edn.). Boston: Allyn and Bacon.

Thaler, R. H. (1980). Toward a positive theory of consumer choice. Journal of Economic Behavior and Organization, 1, 39-60.

Thaler, R. H., \& Sunstein, C. R. (2008). Nudge: Improving decisions about health, wealth, and happiness. Yale University Press: London.

The Hague, municipality of (2005). Promise is debt: The citizen's charter of the parking department in The Hague. https://circabc.europ a.eu/webdav/CircaBC/eupan/dgadmintest/Library/6/1/2/12_austr ia/meeting_25-26_2006/Paper\%2007e\%20flyer\%20citizen $\% 20$ charter\%20The\%20Hague.pdf.

Thomassen, J. P. R., Ahaus, C. T. B., Van de Walle, S., \& Nabitz, U. (2014). An implementation framework for public service charters: Results of a concept mapping study. Public Management Review, 16(4), 570-589.

Thomassen, J. P. R., Leliveld, M. C., Van de Walle, S., \& Ahaus, C. T. B. (2017). Compensating citizens for poor service delivery: Experimental research in public and private settings. Public Administration, 95(4), 895-911.

United Nations. (2003). United Nations guidelines for consumer protection (as expanded in 1999). New York: Department of Economic and Social Affairs. United Nations.

Van de Walle, S. (2016). When public services fail: A research agenda on public service failure. Journal of Service Management, 27(5), 831-846.

Van Doorn, E. A., Heerdink, M. W., \& Van Kleef, G. A. (2012). Emotion and the construal of social situations: Inferences of cooperation versus competition from expressions of anger, happiness, and disappointment. Cognition and Emotion, 26(3), 442-461.

Varadarajan, P. R., \& Menon, A. (1988). Cause-related marketing: A coalignment of marketing strategy and corporate philanthropy. Journal of Marketing, 52(3), 58-74.

Vázquez-Casielles, R., Suárez Álvarez, L., \& Díaz Martín, A. M. (2010). Perceived justice of service recovery strategies: Impact on customer satisfaction and quality relationship. Psychology \& Marketing, 27(5), 487-509.

Vigoda, E. (2002). From responsiveness to collaboration: Governance, citizens, and the next generation of public administration. Public Administration Review, 62(5), 527-540.

Vitell, S. J. (2015). A case for consumer social responsibility (CnSR): Including a selected review of consumer ethics/social responsibility research. Journal of Business Ethics, 130, 767-774.

Wagner, T., Lutz, R. J., \& Weitz, B. A. (2009). Corporate hypocrisy: Overcoming the threat of inconsistent corporate social responsibility perceptions. Journal of Marketing, 73(3), 77-91.

Wang, H., Tong, L., Takeuchi, R., \& George, G. (2016). Corporate Social responsibility: An overview and new research directions. Academy of Management Journal, 59(2), 534-544. 
Wason, K. D., Polonsky, M. J., \& Hyman, M. R. (2002). Designing vignette studies in marketing. Australasian Marketing Journal, 10(3), 41-58.

Wirtz, J., \& Mattila, A. S. (2004). Customer responses to compensation, speed of recovery and apology after service failure. International Journal of Service Industry Management, 15(2), 150-166.
Wood, D. J. (2010). Measuring corporate social performance: A review. International Journal of Management Reviews, 12(1), 50-84.

Zerbini, F. (2017). CSR initiatives as market signals: A review and research agenda. Journal of Business Ethics. https://doi. org/10.1007/s10551-015-2922-8. 